\title{
Indigenous politics, public health and the Cambodian colonial state
}

\author{
Sokhieng Au
}

\begin{abstract}
This article examines controversies surrounding the implementation of the first colonial indigenous health service, the Assistance Médicale, in Cambodia. It characterizes individual and group behaviours in the immediate social conditions of colonial Cambodian society, as well as some of the paradoxes of the modernization narrative ascribed to the colonial science of this period. This discussion supports a more general aim of furthering the understanding of Khmer political behaviour in the colonial period. A history of medical controversies reveals the changing nature of indigenous response to the colonial state, and provides alternative models to existing tropes of Khmer socio-political behaviour.
\end{abstract}

Keywords: agrarian resistance; plague; public health; French colonialism

France had a colonial presence in Cambodia from 1863 to 1954. The colonial government organized an indigenous health service, the Assistance Médicale, for Indo-China in 1905, although Cambodia's service did not effectively begin until 1907. Just as in Europe, the economically debilitating epidemic diseases that regularly afflicted South East Asia provided a major impetus for a health service for the indigenous populations. This article will examine some of the controversies surrounding the implementation of colonial epidemic-control measures and the first colonial health service in Cambodia, the Assistance Médicale (AM). It will characterize individual and group choices in the immediate social conditions of colonial Cambodian society as well as some of the paradoxes of the modernization narrative ascribed to the colonial science of this period.

The intersection between Western (French) medicine and Khmer health provides a unique opportunity in this regard, because the introduction of French medicine in Cambodian society provoked a gamut of responses from the native population. Healing, sickness and death are

South East Asia Research, 14, 1, pp. 33-86 
tightly linked to the 'cultural substratum' of a society, and aspects of medicine introduced by the French were immediately and deeply intrusive into native social life. Intended to discriminate only between the healthy and the sick, these measures impacted on all walks of life from elite to peasant, immigrant to native, colonizer to colonized. ${ }^{1} \mathrm{By}$ examining reactions to the plague, a disease whose aetiology was just being elucidated during this period, this article will also illustrate the contingent nature of 'modernity' in colonial Cambodia. The process of medical modernization was being experienced simultaneously by colonizer and colonized, creating conflicts within the European community as well as between the European and the indigenous population. Ultimately, keeping up with medical developments could be as challenging for the French administrator as the Khmer villager. Claims to 'modernity' during this threshold historical moment were tenuous for both the Frenchman and the Cambodian.

This discussion also supports a more general aim: to further the limited understanding of Khmer political behaviour in the colonial period. The institution of the Western bureaucratic state occurred at the same historical moment as the implementation of new public health policies. As such, Khmer responses to medical measures were negotiated within multiple and shifting understandings of the relationship between the individual and the state. The analyses of medical controversies and conflicts in this period provide alternative models to existing tropes of Khmer socio-political behaviours.

The article first reviews the (scant) history of resistance in Cambodia. It then moves to episodes of the plague in Phnom Penh as a way to discuss protest and resistance among elite society in an urban setting. The confusion among French policy makers during these epidemics also highlights the tenuous nature of 'modern' thinking in this period. The narrative then moves away from the plague and the city to a discussion of active indigenous resistance to French medicine among the largely rural communities in the country. The range of responses to medical measures reveals an important, historically neglected aspect of colonial resistance. Rather than working backwards from large-scale rebellions to identify conditions that created them, this section focuses on these middle-ground events (neither 'everyday resistance' nor widescale rebellion) to understand how non-elite and elite society

Of course, ideal intentions did not determine results, as discrimination on other grounds occurred. 
conceptualized the grey area between extreme duress and everyday calm. These intermediate-level disturbances reveal that economics are not always the only or even the best way to determine what people will fight to protect.

\section{The peaceable kingdom}

In existing historical studies of the colonial period, Cambodia presents an overall veneer of calm. If we characterize the 1884-86 rebellion as the last major struggle against the imposition of colonial rule, Cambodia witnessed little unrest during the colonial period, particularly in contrast to the centuries of destructive warfare that preceded and the bloody decades that followed it. However, while the colonial period was peaceful in political terms, it would be inaccurate to label it a period of non-violence. Political peace was not social peace; lowlevel violence was an aspect of everyday life. The political calm is in keeping with French colonial tropes of the timid and peaceful Buddhist Khmer. However, observers did not only view Khmers as quiet and shy; Khmer social historiography focuses disproportionate attention on the exceptions to such behaviour. Etienne Aymonier, an early French scholar of Cambodia, observed in personal correspondence in the 1880 s that the Khmer race was very slow to anger, but once aroused, had an absolute lack of pity or compassion. ${ }^{2}$ Three decades later, Dr Adrien Pannetier would claim that the mild Cambodian peasant, if pushed, 'was capable of fiery rages' like a 'crazed sheep' (mouton devenue fou). ${ }^{3}$ A late colonial writer would remark, 'the Cambodian's passivity in the face of Annamite infiltration is very often noted. Rather than struggle against the persistent invader, he prefers to leave home and move away, retaliating against him in sudden fits of anger, with robbery and murder'. ${ }^{4}$ Another would write 'the Khmers are extra-ordinarily long-suffering...yet their outbursts are terrible when they have been goaded beyond endurance'. 5

Observers of Khmer culture find this gentle/violent dichotomy so striking that many have proposed a variety of explanations. In contrast

2 Fonds Aymonier, Archives of the Société Asiatique, Paris.

3 Pannetier, A., and Verneau, R. (1921), 'Contribution a l'étude des Cambodgiens', L'Anthropologie, Vol 31, pp 279-317, p 311.

4 Robequain, C. (1944), The Economic Development of French Indo-China, Oxford University Press, New York, p 18.

5 Thompson, V. M. (1937), French Indo-China, Macmillan, New York, p 324. 
to scholarship on similar phenomena such as Malaysian amok, the 'Cambodian' phenomenon is often parochialized. ${ }^{6}$ For example, French scholar

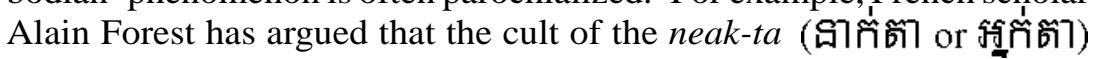
creates intense pressures to conform in Khmer peasant society. An individual does not break with the rules of the society unless some wholly unacceptable situation has driven him to relinquish his role as a social entity. ${ }^{7}$ In such a state, he presumably gives free rein to any suppressed anti- or a-social behaviours. This interpretation however is in direct conflict with two anthropological studies of Khmer village life written in the 1960 s, both of which noted the remarkable social tolerance for individualistic or idiosyncratic behaviour among villagers. ${ }^{8}$ Finding the roots of this 'unique cultural trait' seems to hold such fascination because it is inculpated in the startling violence of the Pol Pot era. ${ }^{9}$ Historical teleology casts the stain of the Khmer Rouge era back into the colonial period and before it.

It is said that social connections in pre-colonial and colonial Cambodia were largely vertical rather than horizontal; this perhaps discourages the 'class identity' sought out by Marxist scholars, and leads such scholars to discount Khmer political consciousness. As one Marxist scholar writes, no significant peasant movements arose because of the individualistic anarchy resulting from 'the lack of corporate units above the family'. ${ }^{10}$ However, the predominance of vertical ties in social

6 See, for example, Benedict, R. (1968), 'The relativity of normality', in Fried, M. H., ed, Readings in Anthropology, Thomas Crowell Co, New York, pp 791-808; Spores, J. C. (1988), Running Amok: An Historical Inquiry, Ohio University Center for International Studies, Athens, OH.

7 Forest, A. (1992), Le culte des genies protecteurs au Cambodge: Analysis et traduction d'un corpus de textes sur les neak ta, Harmattan, Paris, p 91.

8 Ebihara, M. (1971), 'Svay, a rice growing village: 1958-1960', PhD thesis, Anthropology Department, Columbia University, New York, pp 420-423; and Martel, G. (1975), Lovea, village des environs d'Angkor: Aspects demographiques, economiques et sociologiques du monde rural cambodgien dans la province de Siem-Reap, Ecole Française d'Extrême Orient, Paris.

9 Tropes of the binary Khmer character exist to the present day, as scholars resort to terms such as 'the killer behind the gentle smile' to explain the violence of the 197578 period in Cambodian history, when a 'social revolution' led by former schoolteacher Pol Pot resulted in the deaths of nearly one million Khmers at the hands of other Khmers. Pol Pot himself seems to be the binary Khmer personality par excellence. See, for example, Chandler, D. (1992), Brother Number One: A Political Biography of Pol Pot, Westview Press, Boulder, CO.

10 Vickery, M. (1984), Cambodia, 1975-1982, South End Press, Boston, MA, pp 1314. He is seconded by a controversial study by Jan Ovesen, which argues that social obligation in a Khmer village does not extend beyond the family. Ovesen, J. (1996), When Every Household is an Island: Social Organization and Power Structures in 
organization is not unique to Cambodian society, although some claim that Cambodia is unusual in being almost completely devoid of horizontal social obligations beyond the level of family. ${ }^{11}$ But the weakness of permanent horizontal obligations in itself does not preclude mass social movements. The protest events discussed below, such as the 1916 Affair, reveal traditional forms of group protest that are not premised on permanent group structure or identity.

Analysis of contentious politics in Khmer society suffers from these associations. Dissension is, within this existing framework, sporadic, atavistic, violent and parochial. Grievances are largely personal in nature. Ultimately, the tension between the atavistic 'hidden temper' of the Khmer, their general temerity, social incohesion and the rarity of anticolonial protest has not been resolved in studies of the region. If anything, these tropes obscure rather than explain the nature of the Khmer response to French colonial government. By examining a range of medical protests in Cambodia with respect to the changing relationship between the individual and the state, this article will propose the groundwork for a more fruitful model of protest behaviours in the Khmer context.

\section{Quotidian violence}

Low-level violence was clearly an aspect of everyday life in rural Cambodia. The one Khmer monograph recording society and customs in the late nineteenth century describes hardship, ritual killing, and torture of prisoners as commonplace. ${ }^{12} \mathrm{We}$ also have evidence that human sacrifice was practised into the colonial period. ${ }^{13}$ The frequent

Rural Cambodia, Department of Cultural Anthropology, Uppsala University, Sida, Uppsala, Sweden.

11 As Anthony Reid writes, 'All the evidence we have suggests that vertical bonding is very ancient and central to almost all Southeast Asian societies, and cannot helpfully be portrayed as an external or recent factor'. Reid, A. (2000), Charting the Shape of Early Modern Southeast Asia, Institute of Southeast Asian Studies, Singapore, p 185.

12 Tauch, C. (1994), Battambang During the Time of the Lord Governor, CEDORECK, Phnom Penh, pp 25, 47-49.

13 Aymonier observes that in Kompong Svay in the mid-nineteenth century, human victims were sacrificed around the April water festival. He notes that during the time of his writing (1883), 'those condemned to death are not executed in their villages. Without a special order to decapitate them in the place of the crime, they are conducted in a grand "cortege" to the protector tree of the province, with their execution 
references to murder, banditry and warfare in Khmer folklore also point to the mundane nature of violence. However, large-scale or 'political' violence was rare. Unlike neighbouring Vietnam, the Protectorate had few massive upheavals or social conflicts. The lack of obvious drama might explain the sparse historiography of the period. Historians have singled out two events partially as exceptions proving this rule, the socalled '1916 Affair' and the murder of French administrator Felix Bardez. These events merit a brief review because I argue, in contrast to some scholarship, that they suggest traditional forms of protest that were utilized in other contexts in the colonial era.

The 1916 Affair began in November 1915, when hundreds of peasants travelled to Phnom Penh to petition for the King's intercession against excessive taxation and corvée. The aggrieved peasants camped out en masse before the Royal Palace. The location is significant. We will see with other demonstrations that group complaints were also presented to the Royal Palace rather than the French colonial headquarters. The King addressed the petitioners, promising them that the situation would be alleviated. The crowd, seemingly satisfied, dispersed. However, the movement resumed in January 1916, when thousands of peasants from all over the country began arriving at the Royal Palace, all to request relief from the King. The movement had no identified leadership: huge groups with little organization left their villages and travelled to submit grievances personally to the King. Some records estimate that as many as 100,000 petitioners from throughout the country arrived at the Palace. ${ }^{14}$ It was ultimately a non-violent demonstration and eventually dispersed. No Frenchman was injured or attacked during this movement. This, as observed by one administrator, was exceptional for a colonial protest. ${ }^{15}$ Milton Osborne contends that the Affair is representative of a new proto-political peasant behaviour. ${ }^{16} \mathrm{I}$

becoming a sort of sacrifice to the genies. ... These practices would seem to be the vestiges of real human sacrifices which took place up to that time.' Aymonier, E. (1984/83), Notes sur les coutumes et croyances superstitieuses des cambodgiens, CEDORECK, Paris, p 56. David Chandler theorizes that two prisoners of war were beheaded in 1877 on royal orders at the sacred site of Ba Phnom as an offering to the neak ta known as 'white mother', and the new agricultural year. Chandler, D. (1974), 'Royally sponsored human sacrifice in nineteenth century Cambodia: the cult of the Nak Ta Me Sa (Mahisasuramardini) at Ba Phnom', Journal of the Siam Society, Vol 62, No 2, pp 207-222.

14 Osborne, M. (1978), 'Peasant politics in Cambodia: the 1916 affair', Modern Asian Studies, Vol 12, No 2, pp 217-243.

15 Pannetier and Verneau, supra note 3 at p 311.

16 Osborne, supra note 14 at p 240. 
would argue, in contrast, that this behaviour is remarkably similar to other examples of peasant protest in pre-colonial South East Asia. ${ }^{17}$ This link will become more obvious when we later compare it with protests surrounding the plague.

The Bardez murder occurred on 18 April 1925, when a village mob killed French tax collector Felix Bardez. The events, in brief, are as follows. Bardez arrived at the town of Kraan Laev in the morning and called a village meeting. During the meeting, he tied up three village notables and refused to release them until the villagers remitted taxes owed to the colonial government. The villagers, however, simply did not have the money. Several hours later, while eating his lunch before the villagers and imprisoned men, Bardez was approached by one of the imprisoned men's wives. She offered him a small sum of money to release her husband temporarily for lunch. Bardez refused. A scuffle ensued; Bardez's men were attacked, and he was killed. ${ }^{18}$ Although it was widely publicized in Cambodia, in many ways the murder of Felix Bardez was unexceptional. In other words, the fact that a Frenchman was the victim is not exceptional. We see numerous references in the archives, and even occasionally in the colonial newspapers, to the assassination or murder of Frenchmen by indigenous subordinates. The method of Bardez's death is not unusual either. Foreign observers during the colonial period often casually mention offending individuals (pirates, thieves, sorcerers) killed or beaten by a mob. ${ }^{19}$ What is exceptional is the combination of the identity of the victim and the method. That is, the significance of the Bardez death lies in the combination of a mob killing and a French victim within a very public setting. There were no other public uprisings during the same period; the killing was unplanned, and it was not matched by any other tax protests. On a basic level, the killing was not political in that it was as much a reaction against the singularly obnoxious and disrespectful manner in which the man treated the group present as a protest against what Bardez represented (French colonialism).

17 See, for example, Adas, M. (1981), 'From avoidance to confrontation: peasant protest in precolonial and colonial Southeast Asia', Comparative Studies of Society and History, Vol 23, No 2, pp 217-247.

18 For further details, see Chandler, D. (1982), 'The assassination of Resident Bardez (1925): a premonition of revolt in colonial Cambodia', Journal of the Siam Society, Vol 70, No 1, pp 35-49.

19 To my knowledge, no studies exist of actual court cases in the French or Khmer jurisdiction, so it is difficult to assess whether these killings were illegal or sanctioned by the specific group. 
The attempt to interpret these events as evidence of proto-modern political consciousness is ultimately unconvincing without an understanding of pre-colonial political behaviour. Rather, viewed in historical context, the 1916 Affair and the Bardez murder seem to represent precolonial social repertoires of contention known to protestors, repertoires that we will see echoed in many of the responses to public health measures. Such repertoires are 'at once a structural and cultural concept, involving not only what people $d o$ when they are engaged in conflict with others but what they know how to do and what others expect them to do'.$^{20}$ Interpreted within the evolutionary trajectory of Western political traditions, these can appear to be a new sort of political consciousness. Thus, they seem indicative of rupture or evolution in political behaviour. However, for South East Asia, these repertoires seem, in my reading of the evidence, to fall into patterns of pre-colonial 'political' collective action. That is, they seem in many ways to represent continuity rather than rupture in methods of negotiation between the state and non-state actors. The sense of rupture appears when these acts are interpreted by the effective state (the colonial government) and the post-colonial scholar (dependent on colonial documentation). However, the relationship between modes of protest and response to the state was dynamic during the colonial era. As what was 'expected' of protestors changed (along with who was interpreting their actions), protest behaviours and their meanings also changed. These changes, however, I would place later in the colonial and post-colonial period, and I would argue that it was a slower process than is suggested by the scant scholarship available.

Through a history of medical resistance, I will sketch the changing nature of protest against the colonial state. I will first examine the plague in the capital city, before looking at more general responses to medical measures. The many episodes of resistance to French medicine are presented in such a way as to compare and understand commonalities and differences in political options within a wide cross section of indigenous society in Cambodia.

\section{The plague arrives in Cambodia}

On 4 June 1907, Phnom Penh Mayor Collard notified Résident Supérieur

20 Tarrow, S. G. (1998), Power in Movement: Social Movements and Contentious Politics, Cambridge University Press, Cambridge and New York, p 30 (emphasis in original). 
Luce of the first bubonic plague death in Cambodian history. ${ }^{21} \mathrm{~A}$ sergeant second class in the French militia, Tran-Van-Xanh, had died in Phnom Penh two days earlier, his plague-ridden buboes ${ }^{22}$ confirmed by microscopic examination in the bacteriology facility recently installed in the Phnom Penh Hospital. The deceased not only had the dubious honour of being the first official plague death in the history of Cambodia, but was also at the forefront of medical history for having his microscopic killer diagnostically confirmed through laboratory analysis. His death also coincided, more specifically, with the birth of the Assistance Médicale in Cambodia.

Since the devastating Hong Kong plague epidemics of the early 1890s, the colonial government had been trying to prevent the seemingly inexorable march of the disease from points north and west. Despite the government's best efforts, the disease appeared in Annam at the end of the nineteenth century, ironically linked with the Nha Trang research laboratory of the Pasteurian Alexandre Yersin, sent proactively by the French Indo-Chinese government to Hong Kong to study the disease. In April 1899, Inspector General Kermorgant informed the regional administrators of suggested measures for the plague epidemics in Nha Trang and elsewhere: inject the family and those in contact with the patient with Yersin's preventative serum; burn all infected homes in the surrounding perimeter; chemically disinfect the diseased area; immediately isolate the sick and their family in a lazaret; relocate the nearby population to a temporary quarantine village; forbid rebuilding in the affected site for at least a year; make obligatory the declaration of all plague deaths; and urge all neighbouring villages to turn back anyone and any materials from a known infected area. ${ }^{23}$ Kermorgant understated the situation when noting that some of these measures would be difficult to implement. Some eight years later, events would prove that in Cambodia, not only the most draconian, but even comparably mild measures would be impossible to implement. With the first

21 National Archives of Cambodia, Collection of the Résidence Supérieur du Cambodge (NAC RSC) 5427.

22 The plague occurs in three forms: bubonic, septicaemic and pulmonary. The disease manifests itself with fever, chills, headache and extreme exhaustion. Bubonic plague, the most common form, causes painful and localized swelling in the lymph glands. These swollen glands are called buboes in English or bubons in French. The most obvious buboes usual occur in the groin and under the armpits, where the major lymph nodes of the human body are located. A simple physical examination for the plague was thus often quite intrusive.

23. NAC RSC 12837. 
Cambodian plague death, the Phnom Penh doctors were exasperated to find that the sergeant's entire family had disappeared without a trace after being ordered to report to the hospital for preventative treatments. The young Vietnamese soldier was buried under a protective layer of disinfectant chalk two days after his death, presumably with no family or friends present. ${ }^{24}$ This did not bode well for public cooperation with government health measures.

Following the Nha Trang, Annam, epidemic of 1898, Saigon and other locations in Vietnam had registered sporadic plague cases and the occasional minor epidemic into the early twentieth century. The news of plague in Cambodia in 1907 was unwanted, but the growing trade and worker migration between Cochin-China and Cambodia had made the event increasingly likely. Its inevitability did not make its debut any less alarming. In 1907, Cambodia had four AM doctors, at this time all French. The training of indigenous médecins had begun with the opening of the Hanoi Ecole de Médecine in 1902, but as of 1907, none had been posted to Cambodia. The doctors of the AM in 1907 consisted of two physicians at the Mixed Hospital (one of whom, Hauer, also served as the Cambodian Health Director), a mobile smallpox vaccinator, and a medical chief stationed in the port town of Kampot. At the onset of the epidemic, the country's only medical establishments were the Phnom Penh Hospital and the military ambulance in Kampot, although nine new medical posts were planned for the coming year. ${ }^{25}$ With the onset of the disease, the mobile vaccinator Doctor Lannelongue was pulled from his smallpox vaccination work in the countryside and reassigned with a handful of indigenous assistants to patrol the streets of Phnom Penh and investigate potential cases of the plague.

At the end of the nineteenth century, the metropole had drawn up a list of 14 diseases whose declaration to the authorities, or dépistage, was obligatory in the colonies. The French term dépistage entails disease registration through mandatory declaration of the attending physician to the authorities. ${ }^{26}$ In the metropole, the doctor, often in direct conflict with his vow of professional secrecy, was the uneasy link between hygienists, legislators, law enforcers and the lay

$24 \quad$ NAC RSC 5427.

25 By medical establishments, I mean any locale devoted predominantly to medical treatment. Traditional Khmer medicine is practised in the home or the temple, and has no dedicated establishments per se.

26 Dépistage can also mean, simply, medical screening. 
population. In the colony, dépistage did not work exactly as it worked in the metropole because the population did not rely upon governmentlicensed medical professionals. In the specific context of Cambodia, the French doctor - who was first of all a military man, colonist, and administrator - was often the hygienist, legislator and law enforcer. ${ }^{27}$ Since the indigenous population did not turn to the French doctor for daily illnesses, he could not be the liaison between the administration and the general population. His presence was usually an intrusion, hence dépistage in the colonial context was almost always the forced examination of the sick by a public health official. ${ }^{28}$

With French encouragement, King Norodom had abandoned the ancient Cambodian capital of Oudong in 1866 and relocated 50 kilometres downstream to Phnom Penh, a small town at the confluence of the Tonle Sap, the Mekong and the Bassac rivers. Phnom Penh in 1907 was a small but growing city. The colonial government was at this time making a substantial effort to organize the capital of its protectorate kingdom. In a quarter of a century of control, Phnom Penh had grown considerably. In an attempt to provide some order, the administration had earlier partitioned the city into quarters, denoted by both ethnicity and number. In 1907, the city consisted of four quarters, although in later years more would be added. The Chinese quarter, the most densely populated area, was the commercial centre of Phnom Penh. Contemporary photographs and correspondence describe the centre as a place where occupants lived in often haphazardly built and cramped quarters, with livestock living among them, garbage and sewage dumped in the streets and canals, where rats and other stray or unwanted animals roamed freely. The Cambodian quarter was situated at the southern end of town. The Royal Palace was to be found here, along with the dwellings of Cambodian urbanites. The term 'urbanite' was misleading for many of the Khmer in the city, since much of the Cambodian population was newly urban, and the Khmer population in this quarter were in some ways simply creating a crowded village on the outskirts of the Chinese-dominated commerial quarter.

27 By the 1930s, the decreased proportion of military to civilian doctors in the AM also led to an increase in the invocation of professional secrecy, often to the disgust of the supervising military doctors. See NAC RSC 2381.

28 For an detailed definition of dépistage and its functioning in Paris, see Barnes, D. S. (1995), The Making of a Social Disease: Tuberculosis in Nineteenth-Century France, University of California Press, Berkeley, CA. In the metropolitan context, dépistage often included coercion and intrusion as well, but to a lesser degree. 
North of the Chinese quarter sat the French quarter. The final quarter, the Catholic village, was located above the French quarter, at the northern end of town. Both of these quarters were physically separated from the indigenous quarters by a canal that encircled them on all sides (see Figures 1-3). Whether by purposeful French design, ${ }^{29}$ or by the social conditions resulting from colonial economic policies,,$^{30}$ the various ethnicities of the city were, on paper, segregated into relatively discrete geographical locales, although actual boundaries mixed and blurred considerably. The government had attempted to improve canals, build sewers, standardize building codes, mandate weekly cleaning of the open-air markets, and regulate various other behaviours of Asian subject populations, mainly under the banner of improving public hygiene, and most often roundly ignored by city inhabitants. The majority of the city's population was not Khmer. A rough census in 1909 estimated nearly 50,000 inhabitants, with approximately 16,000 Chinese and 11,000 Vietnamese. The French population still numbered under $1,000 .^{31}$

In the initial stages of the epidemic, the plague deaths were concentrated in the Chinese quarter. The authorities implemented measures in a scattershot manner. The municipal doctor examined the suspected dead, usually extracting a sample of the bubo or liver. Some huts were burned; the afflicted were transported to a hastily constructed new lazaret; family members and neighbours were coerced into submitting to the rather painful Yersin serum for the plague. This shot was not only painful, but also produced some plague symptoms, including body aches and high fever. Further, its success rate in preventing or curing the plague proved to be low. In 1907, the serum was used on every plague patient at the lazaret, and the mortality rate was still a staggering $97 \%$. Understandably, townsfolk deeply distrusted the purpose of this serum. The colonial government, rather than questioning the efficacy of the treatment, blamed this distrust on superstition. Health Director Hauer explained:

The preventative use of the Yersin serum was very rarely accepted by those having cohabited with plague victims, because of an interesting story that makes

29 See Edwards, P. (1999), 'Cambodge: the cultivation of a nation', PhD thesis, History Department, Monash University, Melbourne.

30 See Furnivall, J. S. (1956), Colonial Policy and Practice: A Comparative Study of Burma and Netherlands India, New York University Press, New York.

$31 \quad$ NAC RSC 709. 


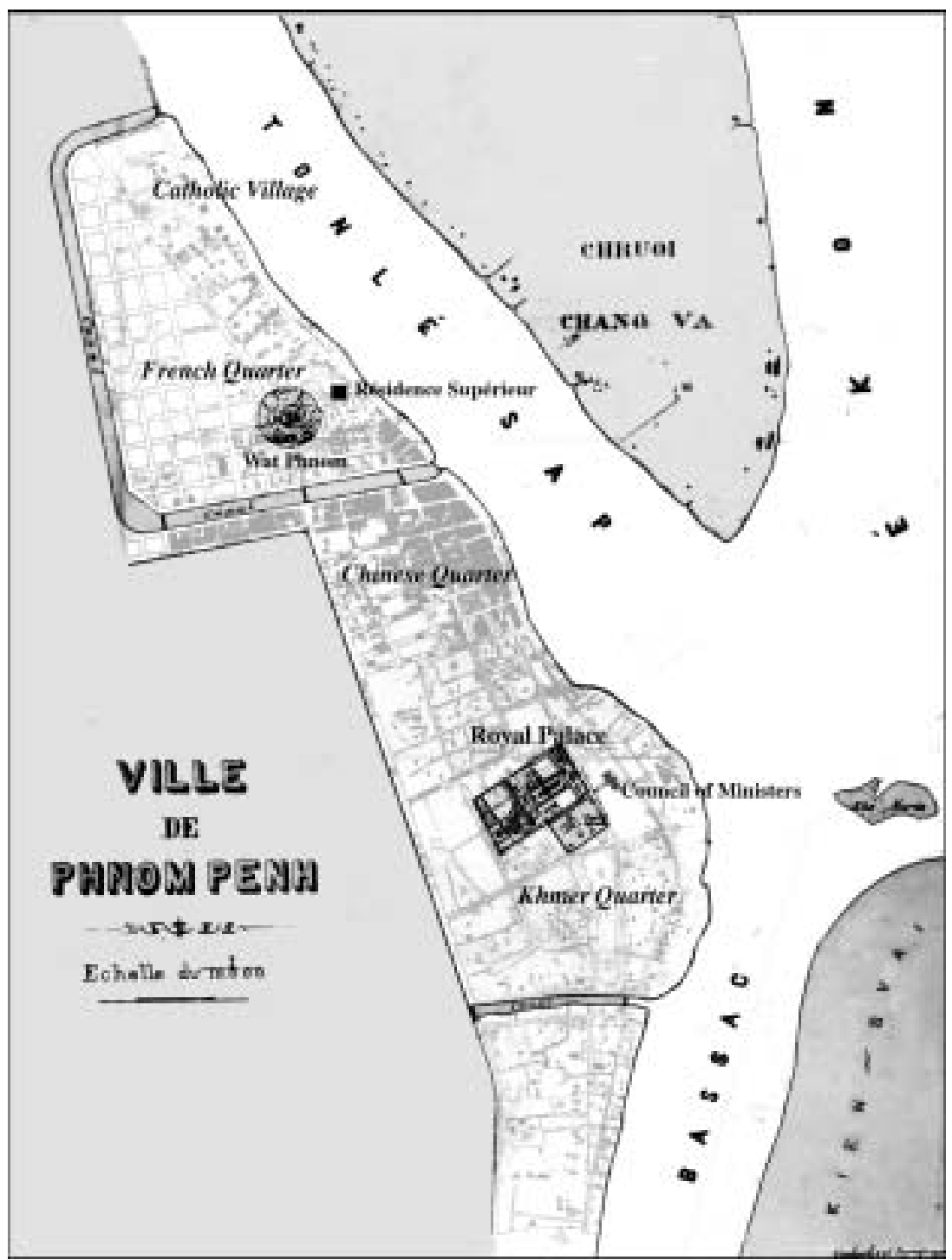

Figure 1. Phnom Penh circa 1910, from NAC File 9315, schematized by the author. Courtesy of the NAC. 


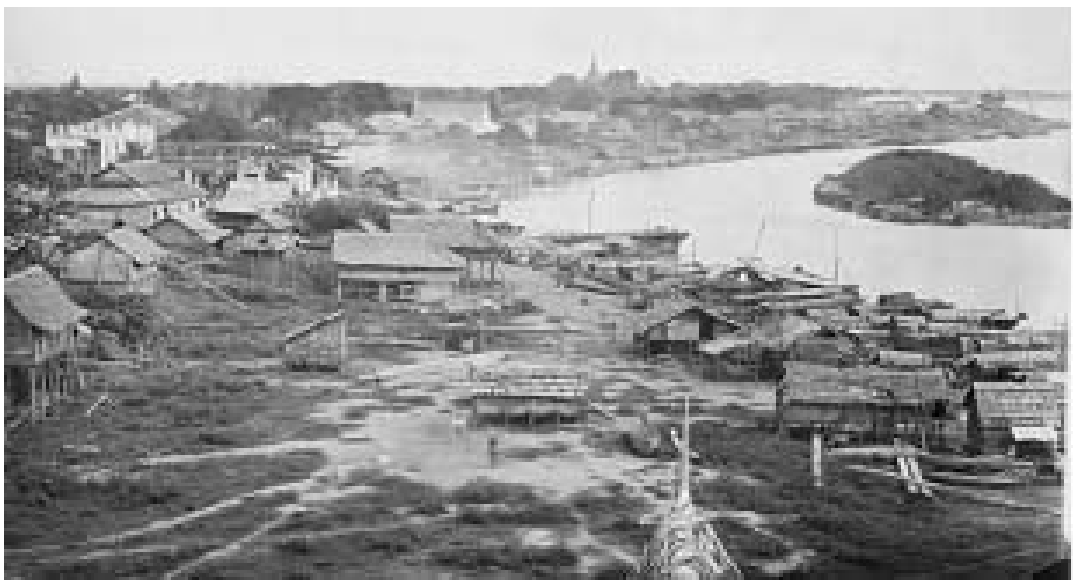

Figure 2. View of Phnom Penh riverfront looking north from the Khmer quarter, circa 1900. The spire in the distance is Wat Phnom, located in the centre of the French quarter.

Courtesy of the NAC.

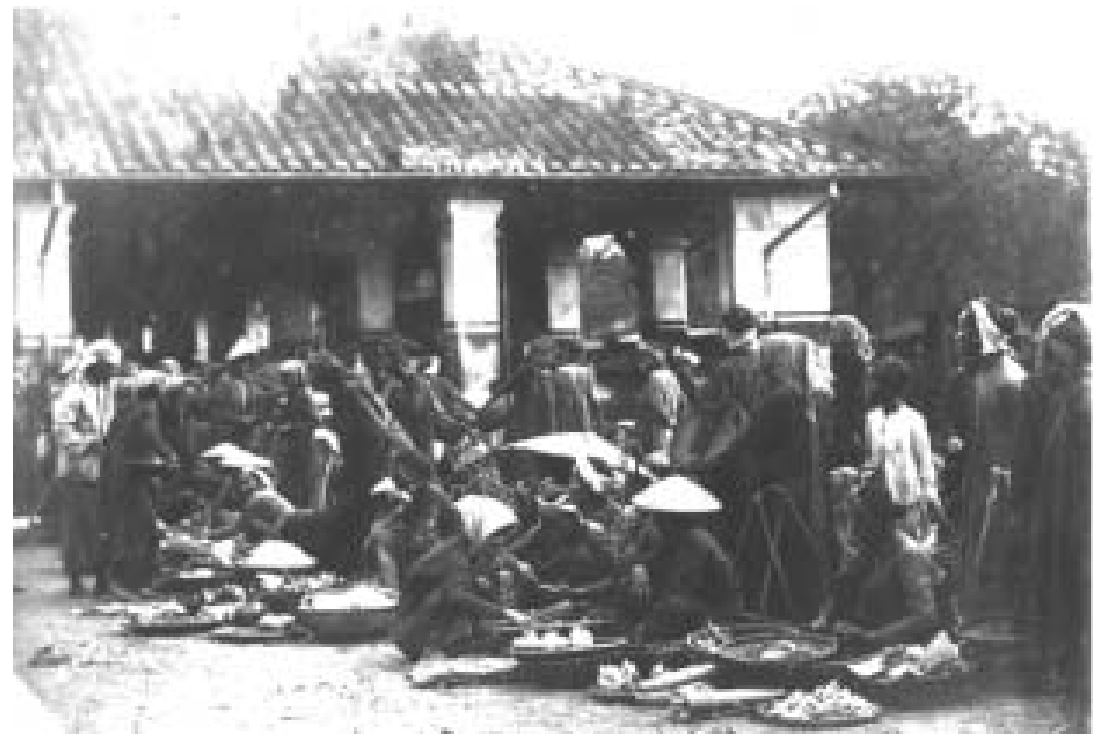

Figure 3. The Phnom Penh market in the Chinese quarter, circa 1892.

Courtesy of the AIP. 
the medication take on a barbaric aspect. It is said that French doctors are opening the stomachs of subjects to take their liver, etc...etc...The cohabitants, wrongly informed by malicious people, fled to the countryside as soon as they understood that defensive measures were to be employed. ${ }^{32}$

This rumour has precedents in Khmer folklore. In the mid-nineteenth century, stories circulated in the countryside of particularly daring and vicious marauders murdering villagers and stealing their livers. Elephants washed or sprayed with a mixture of alcohol and human liver were supposedly rendered invincible in war. ${ }^{33}$ In contemporary Cambodian folklore, 'oil' ritually extracted from female cadavers on the third day after death has powerful magical properties. ${ }^{34}$ The indigenous population, having no experience of government interference with corpses, may have interpreted this manipulation of its dead as in some way linked to other instances of interference with the dead. However, they must also have considered the nonexistent therapeutic value of the painful French injection. Khmers did not willingly give up their sick to dépistage and, forbidden to leave the city, many city dwellers fled under the cover of night into the surrounding forests. Nevertheless, for the better part of a month, the panic seemed relatively controlled.

\section{The 'ridiculous' pig incinerations}

The situation changed on 7 July 1907. On that date, Municipal Doctor Lannelongue discovered the first plague death in the Cambodian quarter, at Boeung (Lake) Pechou. He ordered the immediate incineration of the victim's straw hut, under which he found three pigs living. He brought the matter to the attention of Mayor Collard, who hastily ordered all the pigs in the area to be slaughtered. In a short time, nearly 100 pigs were confiscated and incinerated. The added threat to livestock seemed to have a considerable terrorizing effect, for the flight of city occupants also increased, presumably with their threatened livestock and livelihoods. At the height of the exodus, the authorities estimated that as many as 5,000 Cambodians, or a tenth of the population, fled the city in a single day. Those who did not flee were stirred to further action. As incomprehensible as most of the previous

32 NAC RSC 12624; AM Annual Report, 1907.

33 Pannetier, D. A. (1983), Au coeur du pays khmer: Notes cambodgiennes, CEDORECK, Paris, p 29.

34 Choulean, A. (1986), Les êtres surnaturels dans la religion populaire khmère, CEDORECK, Paris, p 135. 
measures had seemed, they had not provoked widespread public disorder. However, the seemingly arbitrary and destructive nature of this measure provoked a spontaneous public outcry. An angry mob soon gathered in protest. However, just as would happen with the 1916 Affair, the mob gathered before the Royal Palace, not the Résidence Supérieur du Cambodge (French colonial government headquarters). ${ }^{35}$

This measure was incomprehensible not only to Khmers. Public health experts by 1907 had discovered the aetiological pathway of the plague; it was spread by flea bites among human and rat hosts. ${ }^{36}$ No aetiological link existed between the disease and pigs. The Mayor had consulted neither the Cambodian Résident Supérieur (RSC) nor the Health Director before killing the pigs, and both men were puzzled by his reasoning. In his annual medical report to the Inspector General, Health Director Hauer described this measure as 'untimely' and some time later would refer to the incident as the 'ridiculous business of incinerated pigs'. ${ }^{37}$ In defence of his actions, Mayor Collard wrote on 10 July:

[i]f they [the pigs] had absorbed the feces or other contaminated materials fallen from this hut, they would be propagating agents of this evil, either in their waste, or through their consumption [by humans].... Pigs being free to roam in this part of the town, [and] these pigs having surely mixed with the others, I recalled the musings of M. le Gouverneur Général who regretted that, in Saigon, there was some timidity at the debut of the epidemic, I adopted a radical measure; I ordained the slaughter of these animals and their incineration. ${ }^{38}$

This justification is not illogical; however, it did not mesh with the current knowledge of the disease. Although 10 years earlier, the speculations of prominent scientists on plague aetiology had not been far from the Mayor's, laboratory-verified information in those few intervening years had made Collard's reasoning seem ignorant. ${ }^{39}$ Also, while

$35 \quad$ NAC RSC 12624.

36 Paul Louis Simond, one of the early Pasteurians in Indo-China, is credited with what are now seen as classic biological experiments linking the plague to flea bites. Published in 1898, his findings were at first roundly criticized. However, by the early twentieth century, fellow researchers had accepted his hypothesis.

37 'Une ridicule histoire de porcs incinérés', NAC RSC 12624.

38 NAC RSC 32226. Letter from Mayor Collard to RSC on 10 July 1907. The Mayor claimed that he had instructed the health staff to keep a list of pig owners to indemnify; he had even intended to allow the owners themselves to set the pig values. It seems doubtful, with the haste of the killings and the confusion that ensued, that these orders had been followed.

39 For example, plague researcher Alexandre Yersin speculated that the plague germ was spread by ants, flies, or even spores within the ground. 
claiming the need for 'radical measures' and bold decisions in the Khmer quarter, the Mayor (with Municipal Doctor Lannelongue) had refused to cooperate with Health Director Hauer in concerted city-wide public health measures because he feared an uprising among the 16,000 Chinese and any subsequent blow to the economy. ${ }^{40}$ The Chinese, who made up most of the merchant class of the city, held considerable economic clout. The contrast in forcefulness was also in part due to the presumed meekness of the Khmer race, a common theme in French colonial perceptions.

Having disturbed much of the city, the Mayor was at a loss as to how to restore public order. The RSC stepped in and requested the aid of the Khmer elite in calming the crowd. To the annoyance of the Mayor, the princes assigned to the task went before the crowds, and rather than calming them, 'on the contrary excited them further with their xenophobic speeches'. ${ }^{41}$ A few days after the pig killings, King Sisowath visited the Mayor in an effort to bring peace to the city. He agreed to be vaccinated in exchange for the withdrawal of French medical authorities from the Khmer quarter. Since only two cases of plague had been discovered in the quarter, and other attempts to calm the crowds were ineffective as the week passed, the French authorities acquiesced. The RSC decreed that should another case be confirmed in the Khmer quarter, no individual measures would be undertaken and the entire quarter would be quarantined en masse. The King, Khmer officials and the French mayor made the announcement to the crowd gathered before the Banh Yong pavilion. According to Collard,

This crowd cheered with joy and thus emboldened, declared that they didn't want their private lives and illnesses interfered with. Particularly agitated, one group of women had at its head a woman who gesticulated more than the others and screamed her head off 'à tue-tête' that Cambodians did not want to listen to the talk of French doctors, in whom they had no confidence. The Minister of War told me that this woman was a midwife. It is possible to think that she undoubtedly anticipated competition with the Maternity that is to open in a few days. ${ }^{42}$

40 As in many South East Asian nations, the Chinese diaspora constituted the backbone of the merchant class. For a history of the Chinese diaspora in Cambodia, see Wilmott, W. E. (1967), The Chinese in Cambodia, University of British Columbia Publications, Vancouver.

$41 \quad$ NAC RSC 12624.

42 NAC RSC 32225. Letter from Mayor Collard to RSC on 19 July 1907. It is also telling that the woman was a traditional midwife, and as such, one of the groups 
This description is enlightening not only with regard to the state of the Khmer population during this crisis, but also for its description of the active involvement of women in the protests. Although objection to access to a woman's body was common, this is a rare description of women openly participating in a formal protest.

After this announcement, the authorities exempted the Khmer population from most public health measures. Other ethnic groups, however, also had distinct grievances against the epidemic regulations. The Chinese congregation lodged protests about the extended closing of buildings and the transfer of the sick to the lazarets, as well as troublesome disinfection measures such as fumigation by sulphurous gas and whitewashing. Using their commercial clout, the 'Celestes', as they were whimsically referred to by the administration, obtained a major concession from the medical administration when it allowed them in 1907 to open a Chinese hospital.

By the end of the summer, the plague seemed to have run its course; the last official death of the year occurred on 30 September 1907. The city registered 87 confirmed cases, with 83 deaths. The Health Director divided them ethnically into 78 Chinese, three Khmer, five Vietnamese and two 'other Asiatics'. Undoubtedly, more than three Khmers had died of the plague; the surprisingly low number of Khmer victims was most likely due to the lack of medical surveillance in their quarter. But, even taking into account the many dissimulations and hidden deaths among town inhabitants, the death toll was still much lower than the authorities had feared. But although the numbers were relatively small, the impact of this first plague epidemic on the organization of the city's health services was considerable.

Towards the end of the first epidemic, when Doctor Lannelongue was to resume his mobile vaccination runs in the countryside, Mayor Collard argued the need for a permanent municipal doctor, and specifically for the retention of Lannelongue in this role. ${ }^{43}$ Although Collard seemed to have won the general point, as the AM and RSC decided to fund a permanent municipal doctor, Lannelongue's advice (or lack of advice) in the events leading up to the pig killings appears to have led to his return to the provinces. 1908 found him posted as Medical

whose survival seemed, at this early juncture in the development of the AM, dependent on the failure of French medicine. The AM was soon to open a maternity unit in the Mixed Hospital for indigenous women. Her worry over competition would prove unfounded. 
Chief in the nearby, newly created medical district of Kandal. Mayor Collard was also removed from his post. Thus the year after the plague's debut, the city had a temporary new mayor (the renowned colonial scholar Adhemard Leclère) and a new municipal doctor, Devy. Devy, freshly reassigned from the naval service, was presumably better versed either in the newer developments in medicine or in following the chain of medical command. Meanwhile, the Health Director had met the RSC to clarify the role of the municipality and the medical service. They established that the Health Director had primacy in all matters relating to epidemic control; the Mayor was to cooperate with him in sanitary regulations and consult with him before changes in or additions to public health measures. An occurrence such as 'the ridiculous pig incinerations' would not happen again. Further, the newly created municipality had in place a quantity of Yersin's serum, established procedures for dealing with the disease, and a new brigade of indigenous police dedicated solely to investigating and reporting suspected illnesses. The administration seemed better prepared for future epidemics.

\section{Pestilence redux}

The following year, a monk on the Chruy Changvar peninsula, an area to the north-east of the city across the Sap River, was confirmed as a plague victim. The Health Director asked the King to intervene to encourage fellow monks to be vaccinated. When the royal court showed hesitation in taking this active role, Hauer approached the $a a_{a} a^{44}$ of the wat, and with his cooperation organized the vaccination of eight fellow monks in the wat. Only one monk refused the serum and died of the plague shortly thereafter, while no reported cases appeared among the vaccinated. Whether this batch of serum held some preventative properties or these seven monks were merely fortunate was uncertain. This soon became a moot point, as the vaccine quickly fell into short supply, and became reserved as a prophylactic for the sick. The administration raised the bounty for dead rats, from four cents a head at the beginning of the epidemic to 10 cents a head at its height.

At the behest of the RSC, the Khmer Council of Ministers distributed a poster publicizing the dangers of the plague to the Khmer population. A disease new to Cambodia, it was transliterated in the Khmer alphabet, as 'La Peh' (in French 'la peste', \& jl b̂े), as was the 
word 'serum' (6ต่ง รู่ษ). ${ }^{45}$ The original draft of the poster submitted by the Council for French approval referred to the disease as 'rook peh' (6ภากิติติ่) and emphasized the need for doctor's visits and disclosure to public health officials. ${ }^{46}$ However, the final version had significant changes. The announcement distributed in the Khmer quarter was similar to the French, Chinese and Vietnamese posters, with one notable exception: it did not mention dépistage. ${ }^{47}$ In addition, all members of the household and neighbours were to be vaccinated with 'serum'. 'Serum', incidentally, was neither translated nor explained in the announcement. Neither did it mention lazarets or mandatory acts or fines of any sort, although it did note that straw huts in which the disease was found should be burned. Overall, it served as a relatively mild, prescriptive document. ${ }^{48}$ Despite this attempt at public dissemination of necessary information, once again confusion ensued, and once again city inhabitants made for the forests under the cover of night. Authorities blamed unidentified rumours as nearly 10,000 city dwellers fled into the countryside.

\section{Plague in the palace}

This second year of the plague, unlike the first, would significantly impact on the royal court. The tension was already high when one inopportune death triggered massive disorder. A favoured concubine of Prince Duong Mathura, Lady Preng, died suddenly and mysteriously on 8 April $1908 .{ }^{49}$ Duong Mathura was a particularly high-ranking prince, favoured son of King Sisowath, and considered the most likely candidate to be named obbareach (heir apparent). ${ }^{50}$ On the morning of

44 The achaar is the lay ritual officiant of a Buddhist monastery.

45 NAC RSC 26705.

46 NAC RSC 2140.

47 Rather, the document urged inhabitants to avoid rats, which were the agents of the plague; to avoid the dejections and sputum of the sick; to keep surrounding areas scrupulously clean to discourage rats; and to disinfect the land around the house as well as all belongings of the sick and anyone who cared for the sick with 'alcohol,

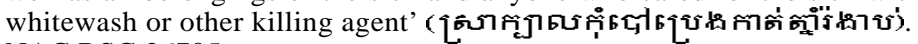

48 NAC RSC 26705.

49 In some French documents, Lady Preng is wrongly identified as Mathura's aunt or his mother. This stems from one incorrect translation of a letter from the Council of Ministers on the subject.

50 Khmer kingship is not determined by rules of primogeniture. The reigning king designates his preferred heir, the obbareach. At the king's death, his wishes are taken into account, but the new king is determined by the Council of Ministers. 
Lady Preng's death, Municipal Doctor Devy came to the palace grounds to examine her body. He and his team were refused entrance to her small home in the royal quarter. Devy left, and returned shortly after at 10 am with a Khmer mandarin. He was met by the sister of Duong Mathura, Princess Somphady, who again turned them away, claiming that the deceased was sealed in a coffin and Khmer rites forbade its reopening. She insisted that the deceased had died of dysentery. In this meeting, the French doctor found her to be 'aggressive, violent, and insolent' ${ }^{51}$ After this second rebuff, Mayor Leclère, at Devy's request, personally requested an audience with King Sisowath at 3 and at 5 pm that day to obtain his intercession with his recalcitrant son; both times he was told that the King was napping. The King was able to grant the Mayor an audience later that evening, after the scheduled hour of Lady Preng's cremation. Unable to prevent her cremation, the health services then decided, as was standard with a suspected death, to order the quarantine of the house for several days. Despite these specific orders, French authorities were exasperated to learn the following morning that approximately 50 people were congregating in the deceased's home. Leclère and Devy quickly convened at the house, where they found five monks performing ceremonial death rites for Lady Preng in front of a crowd of mourners. Not to be deterred by this 'new bravado', the doctor and the Mayor chased all the mourners out mid-ceremony, and ordered the building's immediate incineration. Bystanders seemed both amused and appalled by this administrative daring. The Mayor, in justifying the incident, argued:

It is necessary that the palace residents and the mandarins understand that our authority is superior to theirs, the same in fact for health measures, that the great as well as the small must adhere to the regulations in place for everyone and that individual resistance, no matter from whom, will be punished. ${ }^{52}$

The Council of Ministers defended the actions of the mourners, informing the RSC that the funeral ceremony was a Khmer tradition that had to be performed in the home of the deceased.

Nine days later, on 18 April, a large protest of nearly 1,500 city dwellers erupted, once again in front of the palace, a mob that the administrators were certain was orchestrated by local notables.

51 NAC RSC 2140. Letter from Mayor to RSC Luce on 10 April 1908.

52 Ibid. 
This rowdy crowd claimed that the French doctor was taking the bodies to see the genitalia of the women, on whom they then wanted to have experiments [experiences], attempt fantastic operations. Threats were made, if the king could not aid them then the people were going to resist by force, to oppose the coming of the doctor and the disinfectors - The King demanded time to examine the situation; he requested the Résident Supérieur's participation in a meeting 3 days later, until which time the same turmoil reigned. The local chief attempted to reason with these agitated men, but in vain. In the presence of this state of spirits, the protestors declared that they would sooner prefer to die than to follow our methods, [and] the Résident Supérieur then granted them what they demanded, to no longer concern ourselves with them. ${ }^{53}$

The violence reached its peak on 21 and 22 April, and once again, the colonial government decided it prudent to back down on plague measures. However, the wrath of Duong Mathura was apparently not spent, if he had indeed orchestrated the demonstrations. On 20 April, Duong Mathura had sent a letter to the Khmer Ministry of the Interior requesting an indemnity of 114 piastres for his torched property, Lady Preng's home. This request eventually reached Mayor Leclère. ${ }^{54}$ On 2 May, Leclère sent a strongly worded letter of refusal, pointing out that reimbursement for destroyed property was not required by decree, but if made was simply an act of administrative magnanimity for the sake of an indigent population. The prince was neither indigent nor, in the opinion of the Mayor, deserving of magnanimity. Rather, the Mayor accused him of inciting trouble and fraudulently inflating the value of the house. The refusal was a major slight, particularly considering that the administration had approved every other indemnity request that year. ${ }^{55}$ To add insult to injury, Leclère requested that the King and the Khmer Council of Ministers should bring punitive measures against Duong Mathura and Somphady. ${ }^{56}$ Perhaps the RSC thought it was prudent simply to let the matter lie, for no record exists that he requested formal punishment or reprimand for the royal siblings. It may

53 NAC RSC 2486. AM Annual Report 1908. Cambodian Health Director Hauer.

54 Indemnities for destruction of property were paid out of the municipal budget, over which the mayor presided.

55 A second high-ranking functionary, Khun Pheakdeay Reachea Pen, was granted a relatively small indemnity. He found his house burning when he returned from the funeral of his 8-year-old daughter. At the writing of his request, in early April, his wife had also fallen ill. He requested 84 piastres from the administration and was reimbursed the much more modest sum of 40 piastres.

56 NAC RSC 2140. Letters by Duong Mathura, Council of Ministers, RSC, and Cambodian Health Director. 
have been that by this date, the prince had fallen ill. A few days after the Mayor refused the indemnity, informants advised the Central Commissioner of Police that the prince's faction had publicized that he would pay 200 piastres for the head of any doctor found meddling with the plague. The administration, strangely, took no official action against this brazen defiance. Rather, the health services were paralysed for almost a month, and the number of plague deaths continued to mount. ${ }^{57}$ This year, in contrast to the previous year, many of the victims were among the Khmer elite.

After several weeks, with no end to the epidemic in sight, some of the Khmer elite began to request plague measures. Prince Duong Mathura's death at some point during the month (an unconfirmed case of the plague recorded with some smugness by Health Director Hauer) came as an emotional blow to King Sisowath. It was an advantageous death for the French; after his favoured son's death, the King became much more amenable to colonial public health measures. Whether this was due to the loss of the prince's anti-French influence on his father, or whether his death was a cautionary lesson for the King, following Duong Mathura's demise, the King decided that some public health measures were necessary. However, he urged the administration to move slowly and with care, because, as he explained, the Khmer population did not understand the danger of the disease or the necessity for these sanitary regulations. The health services resumed tentatively, with the final say on any measures in the Khmer quarter being given by King Sisowath. Examination of the deceased was now done with a Khmer delegate of the Ministry of the Interior present, and the destruction of huts permitted only after the recommendation of a mandarin. The Health Director noted the absolute need to get the notables on side if the administration wanted an effective collaboration 'for the sake of the people'. ${ }^{58}$ Genuine cooperation by the elite, he would discover, was an elusive proposition.

\section{Sensitivity and the military man}

While they were carefully negotiating the issue of medical authority over plague measures, the colonial authorities were less hesitant in exercising their punitive authority against the unrest of April. The RSC

$57 \quad$ NAC RSC 2140.

$58 \quad$ NAC RSC 2486. 
demanded that the Council of Ministers undertake an investigation of the mobs and rioting and bring any ringleaders to trial. In mid-May, the Council submitted its findings to the French administration. The report claimed that the lack of precise information precluded the ability to name any wrongdoers. From the 1,500 protestors, its investigators could locate only two complainants, who accused Dr Devy of stripping their dead wives, looking at the women's private parts, and shaving the pubic hair of one. The Council's report describes the complaint of one group:

Neang Sam, who lived with the Service of Elephants, died this past March 26 of asthma...They, the named Prom and Chek, were preparing the body for the funeral rites, when a doctor came to view the deceased. He lifted the cloth covering the corpse, which thus revealed her breasts and ordered them to remove the skirt that she wore, leaving her thus completely nude. The doctor made, in her left hip with the aid of an instrument, a prick about two fingers deep, and he ordered the removal and burning of the huts situated in front of the house, without providing the slightest indemnity. ${ }^{59}$

The plain language of the report took as fact the woman's death from asthma. Although this may have been an attempt to make the health services' presence seem more inappropriate, it is just as likely that the authors could not contemplate a link between the cause of death and the examination of the body in this manner. Further, neutral though the language of the report seemed, the graphic nature of the description also reveals the disrespect perceived from the incident. This short description also illustrates that the municipality did not inform injured parties that indemnities were not provided automatically, but rather had to be requested from the municipal government.

On reading the Council's report, the Mayor was for the most part unsatisfied. He believed that the complaints of disrespect made against the doctor were probably exaggerated. He did suggest that some complaints perhaps 'weren't totally unfounded', because 'military doctors, accustomed solely to treating men, don't always show as much discretion as a civilian doctor'. ${ }^{60} \mathrm{He}$ also noted that, well before he was a mayor, a city doctor had commented to him that the native population had the most violent repugnance at seeing doctors uncovering the private parts of their wives and daughters. When the Mayor discussed the complaints with Devy, including the accusation that the

59 NAC RSC 2140. Letter from Council of Ministers to RSC, 18 May 1908.

60 NAC RSC 2140. Letter from Mayor Leclère to RSC, 25 May 1908. 
doctors only wanted to see the genitalia of native women, the doctor dismissed these arguments with a smile. The Mayor, in a private letter to the RSC, wrote that he would have 'preferred explanations to this smile' along with 'an absolute denial', but that he was certain that for the most part Devy was acting judiciously. As a solution, Leclère asked the interpreter to 'invite' family members to tie a 'well-woven' scarf around the pubic area of their dead and sick women, between and around the thighs (essentially making makeshift underwear) to allay any suspicions. As to the investigation of the Khmer malfeasants, he accused the entire council of making little effort to find and punish the responsible parties. This seems to be a reasonable accusation, considering the paucity of information obtained from the 100 interviews Khmer investigators claimed to have conducted.

\section{Collaboration and dissimulation}

Indeed, the Mayor had reason to be doubtful about the zealousness of the Council. The Head of the Council of Ministers was the Minister of the Interior (Akkamohasêna), Col de Monteiro. The Monteiro family was one of an elite group of Khmer-Portuguese Catholics. Descended from a number of Portuguese adventurers who had settled in Cambodia in the seventeenth century and intermarried with the local population, this Khmer métis group rose to prominence in the Khmer court with the arrival of the French. Their liminal position as being tenuously European, as well as their abilities as translators and businessmen, allowed them to serve as an important bridge between French and Khmer cultures. ${ }^{61}$ Col de Monteiro, who in 1860 began as a clerk and translator for Norodom, had amassed enough power and fortune by 1908 to be considered by colonial observers richer and more influential than the King. ${ }^{62}$

On 31 May, Devy was called to register three plague deaths at Col de Monteiro's property in the Catholic village. At least one of the victims had been sick for nearly four days, and all had had recourse to a $k r u$ khmer before notifying Devy. ${ }^{63}$ The doctor was 'astonished', since Col de Monteiro continually positioned himself as a European and a staunch French collaborator vis à vis the Khmer population. He also

${ }^{61}$ For more information, see Müller, G. (2002), 'Visions of grandeur, tales of failure', PhD thesis, Chapter 3, History Department, University of Zurich, Switzerland.

62 Pannetier, supra note 33 , at $\mathrm{p} 33$.

63 A kru khmer is an traditional Khmer doctor. 
served as the liaison in public health and many other matters between the Khmer and the French administration. Further, Col de Monteiro had volunteered his personal deputy, Oknya Yothea Norin, when the medical services requested a high-ranking official to accompany the Municipal Doctor on his investigative rounds. ${ }^{64}$ Although only one of the deceased was positively identified at the time as a family member (his granddaughter), Col de Monteiro later revealed that the other two victims were his wife and a son. Although one of over half a dozen wives, this one, Salio, was likely to have been his primary wife. ${ }^{65}$

A month earlier, the Council of Ministers had sent RSC Luce a request for a 100-piastre indemnity for Col de Monteiro's deputy, in part for the money he had advanced to informants who had helped him in his plague surveillance work, but also as financial compensation for the hatred and rancour the oknya had endured while accompanying the French doctor. In discussion with the Mayor and the Municipal Doctor, the RSC decided that Yothea Norin was far from deserving a reward, especially in view of his failure to comply with the public health laws when the plague had afflicted his own family. Remarkably, while the oknya was ferreting out other sick individuals for the municipal authorities, he hid his own wife's affliction from the municipal doctor for three days and also had her treated by a kru khmer before taking her to the French hospital, where she subsequently died of the plague. By June, the Mayor, in a state of high frustration at what he saw as unending dissimulation and faithlessness from the Khmer quarter, once again demanded through the Council of Ministers that Col de Monteiro and his deputy be punished 'tam banda sak' - according to their rank. Upon learning of the charge, Col de Monteiro protested to the RSC that he was the greatest advocate of French medicine, having in the past been treated by Dr Hauer numerous times for vertigo. He himself believed in the superiority of French over traditional medicine. The choices made by those around him, he claimed, were completely out of his control:

For the inhabitants of the Catholic village, including those who are either my children or my grandchildren, or my relatives, if they refuse treatment by French doctors, it is because they have their own native doctors whom they have been accustomed to trusting from birth, and it is because they don't yet have

64 An oknya is a very high-ranking mandarin or nobleman; the title is usually conferred by the king.

65 Col had seven other wives who shared a mansion in the city. Salio had the privilege of being the sole matriarch of his home in the Catholic quarter. 
confidence in French medicine. It is not possible for me to force them to be treated by French doctors, considering that the King, the Council of Ministers and you [the RSC], in common accord, have decided not to force anyone. ${ }^{66}$

The Mayor pointed out that Col de Monteiro's statements of his own innocence were contrary to known information - that Col had requested Khmer doctors to treat his sick family members and he neither called nor encouraged the French doctors to come to the Catholic quarter during the several days his family members were sick - and that he should therefore be punished severely. The RSC gave the order to the Council, but no record exists of punishment meted out to either Col or his deputy. In Col de Monteiro's case, it was unnecessary. Six months later, in November 1908, he too died. ${ }^{67}$

Although these men were native political elite, the recalcitrance of Duong Mathura, Col de Monteiro and Yothea Norin must be seen as more than acts of political confrontation. While their mothers, wives and children died around them, these men were trying to make the best choices to protect themselves and their loved ones. It is doubtful whether, even if they had fully cooperated with the colonial health measures, they would have escaped the disease. It is almost certain that their loved ones, already sick with the plague, would have died under either traditional or AM medical care. It seems reasonable to assume that if the AM therapeutics did convincingly save lives, these men would have willingly employed them, despite their 'colonial' taint. Duong Mathura and $\mathrm{Col}$ de Monteiro did not simply die for their politics; nor did they die because of their beliefs.

The epidemic gradually declined in 1908 without actually ending. By the end of the year, 253 deaths had been recorded, with almost a $100 \%$ mortality rate. ${ }^{68}$ In 1909 , the health services recorded 142 plague deaths. The disease had become by its third year more endemic than epidemic. For the next five years, the number of annual plague deaths would rise steadily. The death rate would not drop until 1914, when 305 recorded deaths represented a slight decrease from 327 in 1913.

66 NAC RSC 2140. Letter from Col to RSC, 9 June 1908.

67 The cause of his death is unrecorded. This is despite the mass of archival records created by his death, as his numerous children squabbled in the courts over his amassed wealth.

68 Mortality rates were probably inflated because the rare plague victims who actually recovered were likely never to have been seen or recorded by the authorities. The French were usually notified of only the direst cases; and in most cases, only made a confirmed diagnosis when investigating a death. 
Most deaths occurred in the latter third of the year. ${ }^{69}$ Ironically, the decrease in deaths coincided with another peak in plague controversies. Although friction with the population was most serious at the height of this epidemic, tension had already increased between the French and Khmer administrations over a few cases in the royal quarter early in the year.

\section{The prerogative of elites}

On 30 January 1914, informants revealed to the French Dr Bonnigal that Prince Phat Saweth had allegedly taken or kidnapped a seriously ill 14-year-old house servant named Chau Lak (Liep). Witnesses reported that the Prince had boasted of having magical royal healing powers for the plague and planned to demonstrate these powers on the adolescent. ${ }^{70}$ After Liep died in his care, the Prince ordered the boy's body to be returned to his parents, and promptly disappeared. Phat Saweth's whereabouts in the 10 days following Liep's death were unknown. During this time, neither he nor any of his family had submitted to the plague serum. To complicate the situation further, one of Phat's neighbours had died of the plague on 29 January.

The Municipal Doctor considered Phat Saweth's discovery and detention an urgent matter, not only to bring action against him, but also to prevent further spread of the plague and any further attempts to use his claimed healing powers. To this end, the RSC sent a note to King Sisowath urging him to find and admonish his son, and to order him to 'abstain from practices that are a danger to public health'. ${ }^{71} \mathrm{On}$ 13 February, in an attempt to exonerate his son, Sisowath forwarded to the RSC a letter written by Phat Saweth. In his letter of 11 February addressed to the King, the Prince claimed that he was innocent of the accusations. ${ }^{72}$ The Prince protested that he had known nothing of the

The healing power of Khmer kings, like European kings, is a common myth. See Mak, P. (1995), Histoire du Cambodge: De la fin du XVIe siêcle au debut du XVIIIe, Presses de l'Ecole française d'Extrême-Orient, Paris. Phat Saweth is a prince, not a king - a very important distinction. We may speculate that this kidnapping was related to a desire on his part to prove his kingliness.

71 NAC RSC 12622.

72 Rather, he had borrowed a royal elephant from Prince Duong Leakhena and taken it up to his plantation at Prey Prasat without knowing anything of the plague or any deaths in his house. He argued from this that he could not possibly have boasted about healing plague victims; nor could he have killed anyone. Further, the 
disease until he had returned to find his house fumigated and quarantined. Thus the RSC was mistaken and he was innocent. ${ }^{73}$ Once again, and much to the frustration of French juridical sensibilities, this statement seemed to contradict the known facts. Indeed, the excuses in his letter were flimsy at best; he offered no witnesses to counter accusing witnesses; and his account of dates and locations was vague. But, as before, no written record exists of any punishment against the Prince, and it is doubtful whether the matter went any further.

On 19 May, Prince Chanta Leakhena approached Bonnigal with another complaint involving the maltreatment of a servant. The Prince informed the doctor that a palace servant girl named Kaouc had fallen ill with the plague, and had been carried under his orders to the gunpowder room outside of the palace grounds. The young girl, an attendant to Lady Moniang Molias, was moved into the gunpowder room because she was 'not of a class' that was permitted to die on palace grounds. Although the Prince would have preferred to send her to the public lazaret, the Minister of the Palace, Thiounn, directed him to send the girl to the arsenal. Seeing that she was essentially imprisoned without care, the Prince had requested that Thiounn provide her with some medical attention. When Thiounn failed to respond to his request, Leakhena decided to take the matter to an outside authority, and approached Bonnigal.

When questioned by the RSC, Thiounn affirmed that the servant had been sent to the gunpowder room, since it had been allocated as a plague isolation room for the serving women of the Palace. Claiming ignorance of her three days of neglectful imprisonment, Thiounn added that he had transferred Kaouc to the public lazaret soon after her condition had been brought to his attention. He also argued that the King had never given permission for palace family or staff to be sent to the public lazaret. As a further defence, he pointed out that all Khmer sick with the plague, whether inside or outside the Palace, hid their sicknesses until death or dépistage for fear of isolation in the lazaret or inoculation with the plague serum. Presumably Kaouc, had she been

household servant had gone of his own volition to die in the house of Phat Saweth's mother. He further disputed basic information about the dead child, including his name, which he insisted was actually Krahom ('Red', which is most likely a nickname) and his age (he believed he was five years old). 
conscious, would have preferred the treatment she received to the treatment the French would have offered her. ${ }^{74}$

Thiounn requested that the RSC should have the king clarify the procedure for the isolation of palace staff for any future illnesses. After the French colonial government received this explanation, it did not have enough grounds to censure the Minister. The explanation, however, did reveal Kaouc's palace employer. Bonnigal therefore scheduled a vaccination meeting at the home of Moniang Malias. To his irritation, he found on his arrival that all the adult women had left the residence, and another servant who had contracted the plague had been sent away to an unknown location. In frustration, Bonnigal urged the RSC to block the entire palace area from all public interactions - essentially to quarantine the royal grounds - since, as he saw it, the royal family continued to take gross risks with public health. Such a suggestion was of course impractical, considering that the members of the royal family were still important public figures, even if in actuality they did little governing. It is also important to note that not only royalty, but also Frenchmen resisted the public health measures of the administration. A few months after these deaths, a Mr Eychene, whose next-door neighbour had died of the plague, refused vaccination. He did not accede to vaccination until RSC Luce threatened to place him and his family by force in the public lazaret for eight to nine days. The ability to dissimulate also did not belong exclusively to the colonized. In accepting the vaccination, Eychene claimed that his previous refusal to be vaccinated had simply been a protest at the hygiene service's long delay in executing prophylactic measures at his neighbour's house. $^{75}$

As these episodes reveal, while French medical officials coerced the colonial population into unwanted medical measures, the Khmer elite also imposed unwanted medical measures upon their servant populations. The Prince's inexpert 'laying on of hands' may have outraged the doctor, but certainly no more than the bureaucratic authority of the doctor outraged the elite. Concern for their servants may have impelled Dr Bonnigal's informants to obtain French intercession, but they were also motivated by internal rivalries. For example, Thiounn, as Minister of the Palace, was one of the five members of the Khmer Council of

74 Although no historical record exists of her fate, Kaouc most likely died at the public lazaret.

75 NAC RSC 11614. Letters from Bonnigal, RSC and Eychene. 


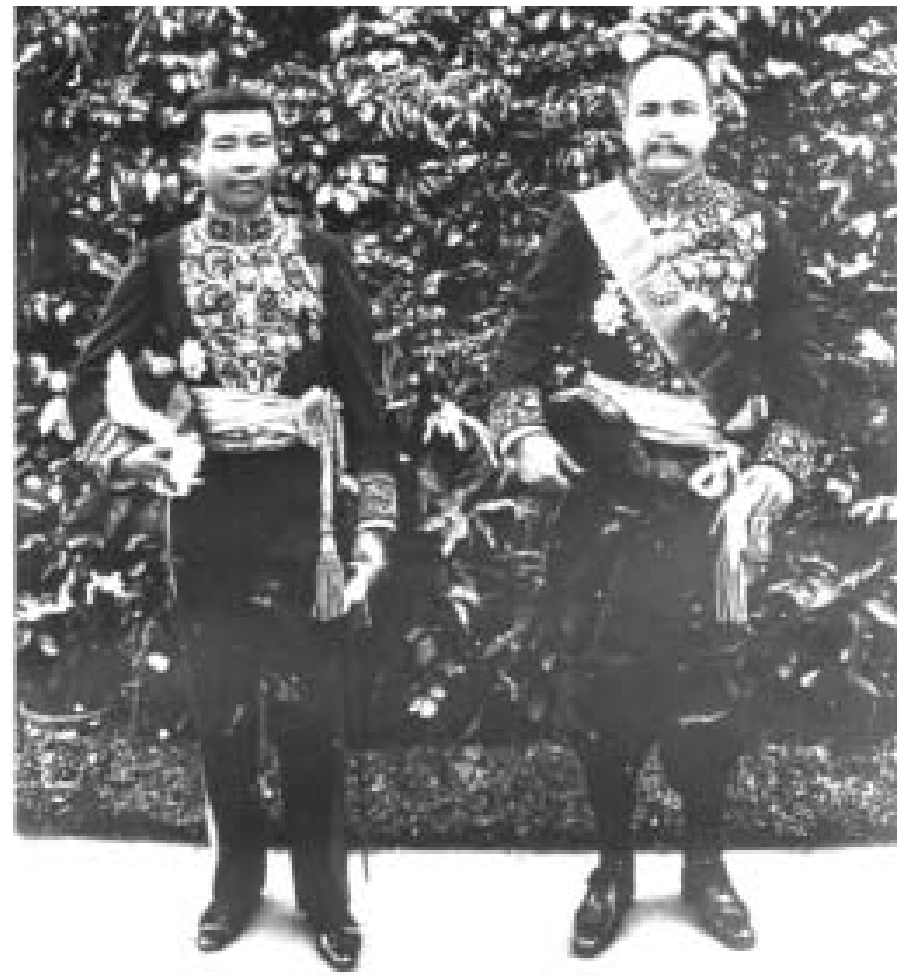

Figure 4. Monivong (left) and Thiounn, circa 1920.

Courtesy of the NAC.

Ministers who determined the succession of the next king (see Figure 4). ${ }^{76}$ Prince Duong Leakhena, a potential heir to the throne who was not on the best of terms with Thiounn, would have benefited from Thiounn's disgrace. Thiounn cleverly exploited the lack of regulatory clarity to extricate himself from responsibility. Within intra-elite politics, the colonial doctor and his regulations could serve as a tool used by one faction against another.

76 This statement must be qualified for much of the colonial period, as in actuality the Council of Ministers rubber-stamped the French colonial government's choice of succession. 


\section{Crossed dialogues}

Elite resistance to plague measures was also due to simple misunderstandings exacerbated by mistrust. In early February, Princess Pathoma, who lived next to a house contaminated with plague, refused to be vaccinated or examined by the French doctor. When her husband died of plague shortly after, she fled to her own residence. The RSC sent a request to Thiounn to arrange a consultation for Bonnigal with Pathoma. The Minister of the Palace approached her with his demand, but she refused to acquiesce. Thiounn dropped the matter, explaining to the RSC that because she was very sick, he could not force her to see the doctor. The very reason the doctor wanted to see the princess was the reason proffered to excuse her from his visit. The princess in her interview with Thiounn explained that both she and her Khmer doctor concurred that her ailment was not the plague: rather, she was suffering from a long-term recurrent vertigo that prevented her from both eating and sleeping. The Minister interviewed others who corroborated her claims to long-term sickness. He reasoned that since she clearly did not have the plague, an injection would not cure it; further, as she was plague-free, she was not a hazard to those around her, and should thus be allowed to forego plague measures.

The RSC, on his part, misunderstood the reasons for Pathoma's resistance. Interpreting part of the Princess's hesitation as fear that the plague treatment would interfere with her current medical regimen, he asked the Minister of the Palace to inform the Princess that 'the antiplague vaccine will not hamper the action of the remedies administered by her doctor'. ${ }^{77}$ This was a misinterpretation on the part of the RSC, since Khmer medical practices often encouraged the concurrent use of various treatments and pharmacopoeia for any given illness. Rather, it would seem that the Princess believed the vaccination to be curative, rather than preventative, for the plague. The RSC's explanation did not lead her to accept the serum. Logically, she assumed that she did not need to be treated for a disease she did not have. In clarifying that she did not have the disease, and failing to understand the basic conception of contagion that was buttressing the French policies, she thus assumed that no other measures were necessary. Since the serum's purpose at times was only preventative, and at other times both preventative and curative, the confusion was understandable. Further, the types and uses of the plague treatment were constantly changing.

77 NAC RSC 12622. 


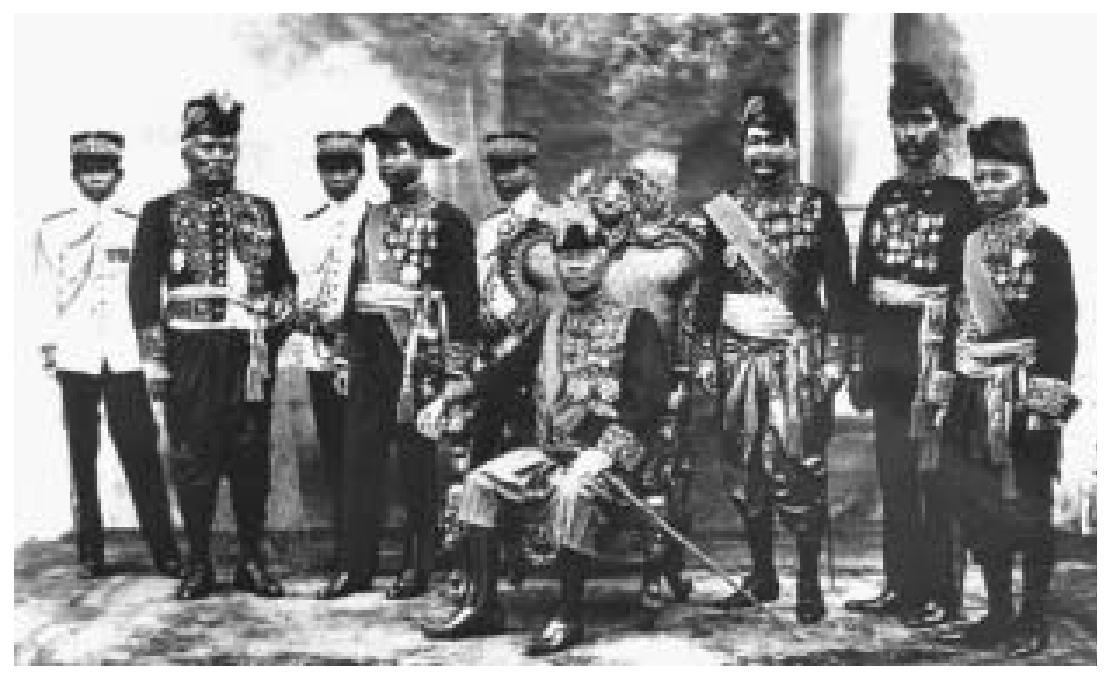

Figure 5. The Khmer Council of Ministers, circa 1920. King Sisowath is sitting in the centre. The Council members are in black. Prince Khanarac is wearing white, standing behind the King immediately to his right. Thiounn, Minister of the Palace, is immediately to the King's left.

Courtesy of the NAC.

Shortly after Pathoma's refusal, Neang Moth, a former concubine of the deceased King Norodom, died. Moth's daughter, Princess Souphana, once again disobeyed health regulations and moved out before the residence or the objects in it had been disinfected. She went to the home of her husband, Prince Khanarac, bringing along Moth's maid, Neang Sam, who was at this time afflicted. Souphana moved the maid into neighbouring Princess Sutharot's house, where she died the following day. Souphana may have believed that having the maid die in a neighbour's house exempted her husband's home from plague measures. However, this was not the case. With Sam's death, both Khanarac's and Sutharot's entire households became subject to plague measures (see Figure 5). Khanarac and his entourage refused to comply with any of the health procedures. As a concession, however, he informed the doctor that he would be willing to be vaccinated at a later date.

Sisowath, prompted by the RSC, asked the Council of Ministers to intervene with Khanarac. The Council called Khanarac to come before it; the Prince, seemingly defiant, refused the summons. The Council 
then sent an envoy to his home to censure him. Khanarac was not pleased. Rather than submitting to admonishment, he apparently scolded the envoy, angered by the language of the initial council summons, and, oddly enough, the disrespectful language of his admonishment. In his view, he had not broken any law. The Prince informed the envoy that he had not been vaccinated immediately after the widow's death because he had been both ill and occupied in planning Neang Moth's funeral, and had no time to become more sick with the vaccination. Later, on 6 March, Khanarac wrote personally to the Council to explain his actions further. He had been unable to appear before them in their initial summons because his left foot was injured and he was confined to his house. As to the doctor's demands, he and his household had been unable to submit immediately to vaccination. If they had, everyone would have been suffering its ill effects and nobody would have been able to arrange the funeral for Moth. Since they had submitted to the injections several days after the funeral, he saw no harm to any party and little reason to continue dwelling upon the matter. Echoing Col de Monteiro, he further argued that he was the greatest proponent of French medicine among his peers; this made the claims against him even more injurious.

Clearly, the death of Moth created conflicting obligations for surviving family members. The family was charged with planning and implementing an extravagant funeral service suitable to Moth's rank. On the other hand, the medical services demanded that Khanarac and his family submit immediately to vaccination. With Khanarac's refusal, we see again that the health services failed to explain the urgent need for vaccination. In Khanarac's view, vaccination was something of a bureaucratic necessity, which, once performed, complied with new health regulations. He did not perceive the direct link between expedited vaccination and epidemic control. If he had submitted to vaccination (with its negative side effects), his ability to cremate his mother-in-law properly would have been hampered. The medical services did not take into account the significance and intricacy of funeral rites for a member of the royal entourage. ${ }^{78}$ They were of immediate importance and needed the attention of family members. Also, the AM did not warn patients of the debilitating effects of the vaccination, although these effects were well known.

78 The importance of burial rites also hampered early attempts at disease-prevention campaigns in Europe. Hardy, A. (1993), The Epidemic Streets: Infectious Disease and the Rise of Preventive Medicine, 1856-1900, Clarendon Press, Oxford, p 273. 


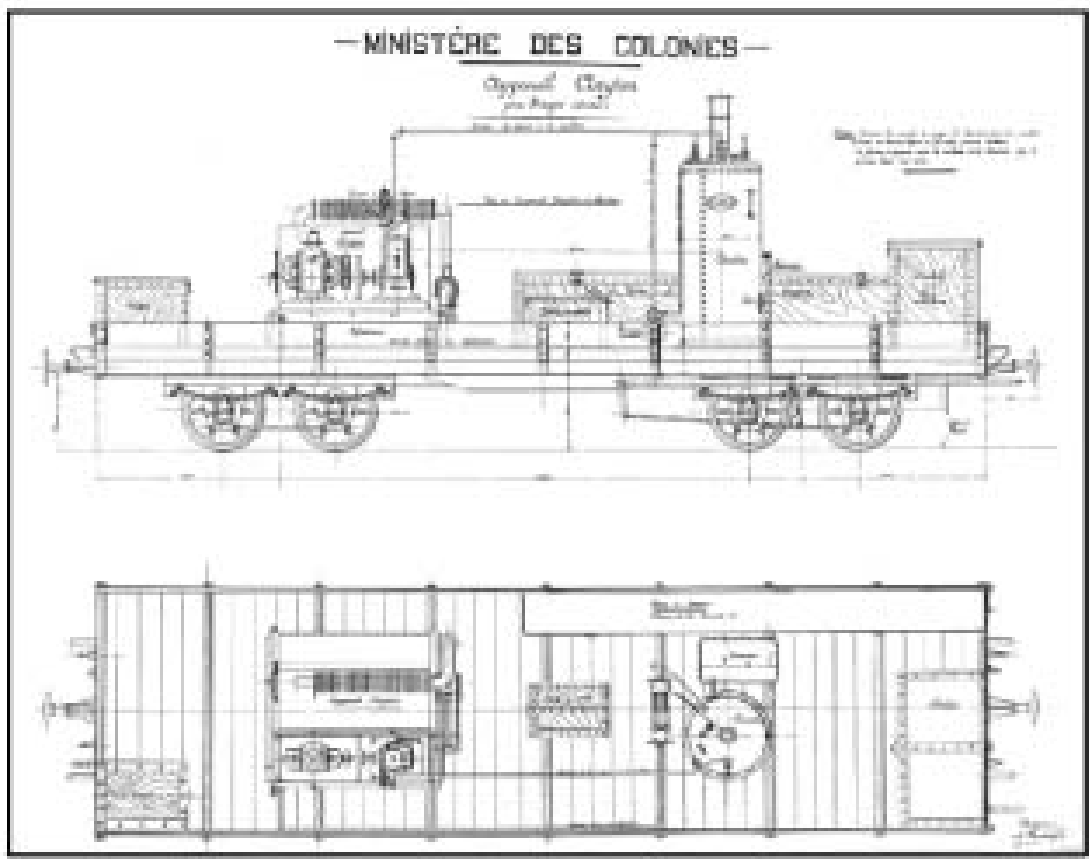

Figure 6. The Clayton Machine (Appareil Clayton) used to pump disinfectant into contaminated houses and ships.

From a French Ministry of Colonies brochure, 1900.

Simple misunderstandings led to serious difficulties. The lack of sufficient warning about the potential negative side effects of certain procedures increased indigenous suspicion of new French medical techniques. For example, when Prince Raya's daughter died on 18 November 1914, Bonnigal sent a polite formal request for the Prince and his entourage to come and bathe 'with soap' at the dispensary's new public bath. Raya refused this demand, telling the King that 'After the funeral rites, I allowed the doctor to vaccinate my family and household, and all developed a fever... In consequence, Highness, please inform the doctors that I cannot go to the dispensary. ${ }^{79} \mathrm{He}$ added that if the Municipal Doctor chose, he could bring Raya the medication and soap and he would bathe at home. The bath probably had no long-term side effects, but as a new technique, there was no way to know for certain.

79 NAC RSC 12622. 


\section{Epilogue to the plague}

By the end of 1914, the municipal health service had various weapons in its war with the plague. Not only was the municipality paying four cents a head for 'civilian' rat collection, it had a disinfection crew and state-of-the-art disinfection equipment that included a Clayton Machine (see Figure 6), a Hercule pump and two Ligner machines, all designed to spray, scour, fumigate and disinfect buildings and boats from a safe distance. Despite the grumblings of the Mayor at the exaggeration of the city's rat problem by the health authorities, the municipality had hired a dedicated rat-killing team consisting of 16 coolies, each paid 40 cents a day plus two cents per rat killed. From early November, four rat-hunting dogs had been placed at their disposal. ${ }^{80}$

Over the course of several years in managing the epidemics, the administration did become increasingly circumspect in its dealings with royalty. In May 1916, two princesses, sisters in their 60s, died within a few weeks of each other. Bonnigal, still the Municipal Doctor, believed that they had succumbed to the plague. Due to the 'corpulence' of the corpses as well as the opposition of their entourage, he was unable to obtain an organ sample, and thus decided simply to assume it was the plague. This time around, the health services also waited for the written permission of the King before demolishing the house and closing neighbouring houses for 10 days. ${ }^{81}$

One of the last plague conflicts with royalty on record involved, appropriately enough, one of the characters from the initial conflicts. This occurred in March 1918, when a 14-year-old girl named Sac died of the plague. Sac worked as a servant in the palace, but lived off the palace grounds. The AM injected her surviving family with the Yersin serum, and disinfected her house with cresyl. ${ }^{82}$ On the day of Sac's demise, another widow of former King Norodom ${ }^{83}$ also died of the plague, after again being isolated alone in a room, unattended and unguarded. While the palace authorities presented Sac as the widow's attendant to medical staff, further investigation revealed that the servant girl did not work for the deceased widow. She was actually a servant to Princess Somphady. Somphady, as we will recall, was the

NAC RSC 2480.

NAC RSC 12622.

82 The preferred disinfectant, sulphurous gas, was not possible due to the state of the home. A house needed to be relatively airtight and sturdy to be gassed.

83 King Norodom had had dozens of wives and concubines. 
sister of Duong Mathura, who had died of the plague seven years earlier. Although the palace staff attempted to deflect attention from the Princess by misrepresenting Sac's employer, Somphady again became subject to plague measures. The Princess, after seven years of plague controversy, still refused, and no doubt had reason to refuse, to be vaccinated and to have her home disinfected. The administration decided this time not to force the issue. ${ }^{84}$

As this section has illustrated, the responses of the Khmer elite to French medical measures ranged from open defiance to open collaboration. Most fell somewhere in the middle. These vignettes also reveal the intra-elite political negotiations among those with political power, and their manoeuvres to maintain that power internally and vis à vis the colonial state. In contrast, the non-elite did not have the leverage to defy government authority with impunity. From their end came other forms of defiance and negotiation. The second half of the article will analyse responses from these less powerful individuals, including ethnic minorities and the rural population.

\section{Peasant responses}

The analyses in this section are informed by the scholarship on subalterns and peasant resistance. They are also influenced by studies on contentious movements and collective action, particularly the work of Charles Tilly and Sidney Tarrow. ${ }^{85}$ Recent scholarship, most pertinent in this context being James Scott's work on South East Asia, ${ }^{86}$ contends that open, individual resistance from peasants in a traditional society $^{87}$ to unjust acts is not viable because the powerless have no institutionalized protection from repercussions. Thus, they resort to weapons such as foot-dragging, gossip and anonymous sabotage. Scott's analysis focused in large part on a contemporary village in Malaysia

$84 \quad$ NAC RSC 32226.

85 Tarrow, supra note 20; Tilly, C. (1986), The Contentious French, Belknap Press, Cambridge; Tilly, C. (1995), Popular Contention in Great Britain, 1758-1834, Harvard University Press, Cambridge, MA.

86 Scott, J. C. (1985), Weapons of the Weak: Everyday Forms of Peasant Resistance, Yale University Press, New Haven, CT; and Scott, J. C. (1990), Domination and the Arts of Resistance: Hidden Transcripts, Yale University Press, New Haven, CT.

87 I take Scott to mean traditional society as one that controlled by traditional authority versus, for example, a legal-bureacratic authority as defined by classical sociology. See, for example, Weber, M. (1947), The Theory of Social and Economic Organization, The Free Press, New York. 
and the social negotiations between poor farmer and native elite. In the colonial context, this analysis might be extended to the powerlessness of the highest echelons of native government, as a weaker group vis à vis the colonizing power. ${ }^{88}$ As Michael Adas observes, a focus on less dramatic acts 'redirects our attention to the larger context in which peasant communities operate and to their ongoing struggle to scale back the demands of the state and elite groups and, thereby, retain enough of what they produce to build decent lives for themselves' ${ }^{89}$ These types of 'everyday resistance' are often, by their clandestine nature, nonconfrontational. Here, I would like to focus on the methods the lower classes had of confronting authority, acts slightly more extreme than everyday resistance. In colonial Cambodia, we can identify three major repertoires of confrontational contention: group demonstrations, petition and evasion. ${ }^{90}$ These repertoires are distinct from some of the methods of the elite classes because they are all collective actions.

\section{Group demonstrations}

The Cambodian lower classes rarely had the luxury of open, individual defiance to the state, although the development of the newspaper, the juridical system and other legal-bureacratic social structures would lead to a shift in their methods of dissent later in the colonial period. Dissension at the beginning of the twentieth century was often expressed in ways that both concentrated the strength of the message being delivered, and diffused, if not always erased, individual responsibility through the group. The group demonstrations such as those after the pig slaughter of 1907 and the palace torchings of 1908 constitute one type of group protest. When the Council of Ministers opened an inquest into the 1908 riots, its investigation was confronted with the usual issue of the anonymity of the 'mob'. Even if there may have been some truth in the claims of the French administration that the protests of 1,500 people in 1908 were engineered in part by the Khmer elite, the

88 As we saw, the Khmer elite frequently resorted to foot-dragging to avoid direct conflict, even if they were also able to employ open defiance in certain circumstances with relative impunity.

89 Adas, M. (1992), 'Comment on "From avoidance to confrontation", in Dirks, N. B., ed, Colonialism and Culture, University of Michigan Press, Ann Arbor, MI, pp 127134, 127.

90 My concept of 'evasion' is identical to Adas's concept of 'avoidance protest', flight or movement to escape the purview of certain political measures. Adas (and Scott) contends that avoidance protest is openly challenging - it is meant to be noticed by the authorities. 
protestors were also no doubt motivated by the panic and disorder caused by misunderstanding and suspicion of French motives. ${ }^{91}$ Further, the Council's inability or unwillingness to place blame clearly was facilitated by the nature of the act.

It would be incorrect to draw a strong distinction between the group demonstration and the petition in the Khmer context. Often, as with the 1916 Affair and demonstrations over plague measures, a group would gather first to voice complaints to the authorities - essentially presenting an oral petition - before resorting to violence. The division between the two types of act appeared more pronounced as the Cambodian population became more literate. In other words, petition cosmetically changed to become a process of written complaint. Oral petitions also became less legitimate because French observers tended to interpret oral petitions and crowd demonstrations in a single inaccurate category of mob violence. Although how Khmers express contention begins to divide earlier in the colonial period, the reasons behind these acts, and how authorities interpret them, do not necessarily change at the same moment. I will examine a few specific cases of petition to further this argument.

\section{Petition}

On 5 October 1914, the five chiefs of the Chinese congregations and one chief of the Annamite congregation submitted a petition to the Mayor of Phnom Penh demanding the relaxation of certain plague measures. They requested that the eight-day mandatory closing of infected apartments should be reduced to two or three days, with proprietors no longer required to pay for disinfectant costs. In exchange for this, the petitioners listed the terms they would accept. ${ }^{92}$ The section chiefs and nearly 100 petitioners signed the petition in Chinese characters. Later plague documents reveal that the duration of the closing of buildings

91 Crowd historian Rudé observed that scholars and authorities too readily discredit the ability of the lower classes to organize spontaneously, and as such are quick to identify outside agents of conspiracy. Rudé, G. (1964), The Crowd in History, 17301848, Chapter 15, John Wiley \& Sons, New York. Rudé argued in part against previous crowd scholars such as Gustave LeBon, who portrayed most crowds as atavistic and mindless.

92 These measures included: (1) annual whitewashing of buildings; (2) disinfection of the 'locale' of a plague death (although presumably surrounding apartments and buildings would be exempted); (3) closing of chambers for two to three days; and (4) burning of belongings when absolutely necessary, in the presence of their owner. NAC RSC 2480. 
was not appreciably reduced, although the use of fire tapered off over the next few years. This may have been due more to financial exigencies than conciliatory politics. The Kampot Medical Chief noted of housing incinerations that,

[i]n reality, their destruction by fire creates major inconveniences: loss of money for the inhabitants, because the indemnity never covers the cost of a new hut, and loss of housing for those who are thrown on the street. For these reasons, the administration decided at some time in the beginning [of the epidemic] that it would content itself with the removal of the roofs of these contaminated habitations, and to leave their interiors exposed to the air, rain and sun, the best natural disinfecting agents, for a certain number of days. ${ }^{93}$

In any case, the burning of commercial goods was of greater concern to the Chinese than the incineration of their homes; richer than their Khmer neighbours, their homes were often built of materials sufficiently sturdy to enable chemical disinfection rather than total destruction. As in the case of the mob protests, the government was quick to blame the merchants' complaints on outside agitation. The Mayor fingered a French entrepreneur named Portret who lived in Mytho (Cochin-China), a proprietor of many buildings in Phnom Penh, as the source of the Chinese complaints. ${ }^{94}$ Although the Mayor may have labelled Portret as the instigator to discredit the Chinese complaints, it is likely that Portret merely participated in formulating the grievance. As a Frenchman, he would have been more versed in methods of negotiation with the colonial government. This petition may have played only a small role in assisting the Chinese in obtaining concessions from the colonial state. However, it did help establish a pattern of productive communication between the two groups that continued through the colonial era.

On 21 April 1924, the Cham population on the Chruy Changwar peninsula filed a petition with the Résident Supérieur. Champa was an ancient kingdom that was gradually absorbed by the southward expansion of the Vietnamese after the fifteenth century. The Cham people, remnants of this kingdom, had dispersed into parts of Vietnam, Laos and Cambodia, where they maintained themselves as a somewhat distinct group with their own language, customs and the Islamic religion. Due to their Islamic religion, the French often referred to them as Malays or 'musulmans'. In terms of public health, they were a mild thorn in the side of the French administration. Among the indigenous

93 NAC RSC 630. 1924 Kampot Annual Report.

94 NAC RSC 2480. 
population, they had a reputation as powerful sorcerers, including in the medical arts. The Cham practice of 'variolation', outlawed since 1919 , and their continued refusal of smallpox vaccinations was, in the French view, a constant obstruction to the eradication of smallpox in the colony. The French had issued a circular on 25 February 1919 authorizing the expulsion of foreigners who practised variolation, as well as fines and jail for all others. ${ }^{95}$ Although many of the Cham communities had lived for centuries in Cambodia, French observers viewed them as 'a world somewhat apart from the indigenous world' ${ }^{96}$ As such, they had the strange status of being classified as foreigners when bureaucratic expediency demanded it. The wording of the circular left this ethnic group vulnerable to expulsion, although the Chinese communities also persisted in practising a form of nasal-swab variolation and were likely to have been the primary target of the circular. ${ }^{97}$

With the exception of the largely unenforced legislation on variolation, Chams were left largely to their own devices. In previous years, the Cham community was outside the jurisdiction of public health measures in the main part of the Phnom Penh municipality, although its proximity to Phnom Penh had led to some death registrations, as witnessed by the first case of 1908. But the Chruy Changwar community became the newest quarter of Phnom Penh in 1924 (the sixth), and had to accept a new dispensary in its midst. To their great displeasure, the Chams found themselves suddenly under the purview of French sanitary law.

Submitted in French, the petition had over 300 signatories, names signed in both the Khmer and Arabic alphabet. ${ }^{98}$ The petitioners were willing to accept all sanitary measures with the exception of the autopsy, which violated the laws of Mohammad. An autopsied cadaver, they explained, could no longer be mummified in the way Islamic religious death rites demanded. They argued that 'autopsies practised

95 NAC RSC 18290, Circular \#28, 25 February 1919.

96 NAC RSC 680. Fabry's 1924 Kompong Cham Annual Report.

97 For more information on the competition between vaccination and variolation in Cochin-China, see Annick Guénel's two articles: Guénel, A. (1996), 'La lutte antivariolique en Extrême-Orient: Ruptures et continuité', in Moulin, A. M., ed, L'Aventure de la Vaccination, Fayard, Paris, pp 82-94; and Guénel, A. (1995), 'Lutte contre la variole en Indochine: Variolisation contre vaccination', History and Philosophy of the Life Sciences, Vol 17, pp 55-70.

98 The Cham language had no specific written alphabet at the time. Written communication and religious learning were undertaken in Arabic. 
on the cadavers of Cambodians, Annamites, and Chinese, which their religions permit, should be sufficient in permitting the public health services to combat epidemic microbes' ${ }^{99}$ The assumption that the health services would be able to carry out its duties by filling a quota of autopsies reveals, once again, that the subject populations had a fundamental misunderstanding of the purpose of surveillance or the diagnostics of plague. The purpose of epidemiological tracking was not simply to collect a certain number of samples, but to monitor and control the disease. The Cham population concurrently submitted a petition in Khmer to the Khmer Council of Ministers, in which, beyond the complaints it presented to the French, it added that the French doctors exposed the intimate parts of Cham women, an act also contrary to the laws of Mohammad.

Municipal Doctor Bouvaist saw little merit in the complaint. In his opinion, the use of the word 'autopsy' was incorrect and exaggerated, since the municipal staff only removed 'a fragment of hepatic pulp and a bit of crural ganglion' from each corpse. ${ }^{100}$ All other ethnic groups including Europeans and the Indian 'musulmans' submitted to these measures, and the Chruy Changwar population could not be exempted, particularly since the dispensary of Chruy Changwar had been installed principally to monitor epidemic diseases. However, the RSC, to be thorough, requested an investigation by the Khmer Council of Ministers. The resultant study found that in the process of mummifying, the Chams massaged the gut of the dead 'to expel from the anus all that could be expelled' (pour en faire sortir par l'anus toute ce qui peut sortir). '[T]he incision produced at the level of the liver to obtain a sample of this organ, wasn't sutured, [and] the intestines spill out through this incision at the moment of the stomach massage.' This, understandably, upset the sensibilities of surviving family members. Health Director Vallet gave the rather perfunctory order that after taking the liver sample, the medical staff were to suture the gut of the corpse to prevent the intestines from extruding. No other concessions were granted to the Chams. ${ }^{101}$

Petitions were not organized solely in Phnom Penh, and did not

By the 1920s, diagnostics were often done on a sample of a major organ rather than on a simple blood or lymph sample. This was in part due to the desire to avoid upsetting the population by performing too intimate an examination. Ironically, a liver sample was less intrusive than examination of a swollen bubo under the arm or at the groin. NAC RSC 1346.

101

NAC RSC 1347. 
involve just the plague, although the colonial administration's constant preoccupation with the plague leaves a particularly good record with regard to this disease. There are some modest petitions against other aspects of the medical service. In 1931, the inhabitants of Kompong Cham submitted a group petition against the local medical chief, Dr Fabry. In their complaint, written in Khmer and translated into French, the townsfolk listed several wide-ranging grievances against the doctor. ${ }^{102}$ Fabry, it seems, was not simply a bad doctor, but also an abusive human being. Of the litany of complaints against Fabry, the most detailed concern his favourable treatment of rich Vietnamese over poor Khmer. ${ }^{103}$ Further, Fabry's wife participated in the exploitation, verbally abusing staff, co-opting them for domestic work, and occasionally sending them to buy her groceries with their own money. The hospital support staff and townsfolk claimed that the doctor had seized the lands of several peasants and claimed them as his own. The petitioners pleaded with the administration to open a wider investigation, because the doctor was a very 'clever liar' to his superiors. ${ }^{104}$ It seems there was no investigation, and there is no record of any disciplinary action against Dr Fabry. But the petition was not wholly ineffective: he was removed from Kompong Cham. This move was a boon for both the citizens of Kompong Cham and for Fabry. In 1932, the Health Director moved him to a more desirable posting, replacing the disgraced Dr Escale as the attending doctor at the Mixed Hospital, Phnom Penh. ${ }^{105}$

We have scattered references to group petitions on more mundane issues, for example in 1936 and again in 1938, the indigenous nursing staff submitted a group petition for a pay rise. ${ }^{106}$ They submitted their petition to the Health Director, and also, innovatively, to the newspaper. The use of the newspaper for a petition was a relatively new development in the 1930s, placing these issues in a public forum for discussion. As one journalist opined, 'if at the hospital one hears many patients complain of the negligence of the personnel, one need not be too surprised. How can we expect conscientious service from employees whom the Administration has treated with a total lack of

\footnotetext{
102 Only the French translation exists in the record.

103 NAC RSC 14582.

104 NAC RSC 14582.

105 NAC RSC 23033.

106 NAC RSC 11996.
} 
conscience?' ${ }^{107}$ This support for the indigenous nursing staff continues through the late 1930s in colonial newspapers such as La Verité, La Press Indochinoise and the Echo du Cambodge. The early 1939 articles in the Khmer edition of the Echo du Cambodge are also the first examples of an effort to garner public support in relation to a medical issue that I have found in the Khmer language. ${ }^{108}$ The appeal to the 'public' for support, and indeed, the very idea of a 'public opinion' challenging authority marks a significant shift in the concept of political power and authority.

Written petitions are phenomena of urban centres, where the populations were relatively educated and literate. On occasion, these petitions were submitted concurrently to both the Khmer administration and the French colonial government. Some, it appears, were submitted solely to the French colonial government. Although few records survive of Khmer administration during the colonial era, it is reasonable to speculate that the reverse happened just as often. In other words, petitions were submitted to the Khmer administration without being forwarded to the colonial government. This is supported by the evidence we have of group demonstrations and oral petitions. Consider that for the largely illiterate peasant populations, petitioners travelled personally to lodge complaints en masse and always to representatives of the indigenous government. Again, the nature of such protest would preclude its inclusion in the historical record. Only personal petitions of the largest and most unusual sort, such as the 1916 Affair, survive in the archives. One rare exception occurred in June 1920, when the villagers of the small town of Moung-Russey in the western province of Battambang came en masse to their town chief to request the temporary release of an illegal variolator named Chau Pech. The unfortunate Pech had been detained in the Battambang provincial centre, a victim of one of the occasional AM attempts to enforce its anti-variolation legislation. The village chief wrote a letter on behalf of his villagers to the Khmer provincial governor, who forwarded his request to the French résident of Battambang. The villagers asked for Pech to be temporarily released for 15 days to complete his inoculations of the village. They clearly did not see the reasoning behind the incarceration of Pech - namely, to prevent him from performing these

107 La Verité, 'Messieurs faites vous infirmiers. Soyez infirmières Mesdames', 18 January 1936.

108 NAC newspaper collections and newspaper clippings, 1936-39. 
'dangerous' variolations. Some of the village children were already developing smallpox, and the villagers, while not understanding why he was imprisoned, believed that his temporary release was vital for their health. The French medical chief refused the request; however, he sent the indigenous médecin immediately to vaccinate the entire region. ${ }^{109}$

Ultimately, the group demonstrations and oral petitions take place at the site of Khmer authority and not French. Demonstrators went before the king, the mandarin and the village chief - not the RSC, the AM doctor or the mayor. Cambodia was technically under a system of indirect rule. The 'traditional' Khmer ruling classes remained the buffer between colonial administration and most of the population. While their actual power to make political decisions was in large part illusory, Khmer elite authority in the eyes of the peasantry was clearly still legitimate. If petition in Europe shifted in the late eighteenth century from the 'tool of private interests seeking redress to a public act seeking justice in the name of general moral claims', ${ }^{110}$ in the South East Asian context, the petition is an established pre-modern form of collective action against the state. ${ }^{111}$ These distinctions point to a fundamental difference in the perceived relationship between the individual and the state in the Khmer and French interpretation, differences to which I will return in the final discussion.

\section{Evasion}

As the stories of the plague reveal, the purpose of local action, or reaction, was often simply to escape the purview of French medicine. Other acts attempted to notify the elite of state measures viewed as unacceptable by the population at large. As we have also seen, constructive measures such as petitions were discouragingly ineffective, while more destructive acts such as rioting seemed more effective. However, destructive acts, by their very nature, were not simply damaging to the French administration, but to local life as well. More

109 NAC RSC 7634.

110 Tarrow, supra note 20, at p 38.

111 Group oral petitions have precedents throughout South East Asia. For example, Takaishi Shiraishi describes 'nggogol' as a pre-communist legitimate form of collective action whereby a group of individuals complains in person to the authorities. Shiraishi, T. (1990), An Age in Motion: Popular Radicalism in Java, 1912-1926, Cornell University Press, Ithaca, New York. Michael Adas also discusses the common use of this method in pre-colonial Java and Burma. Adas, supra note 17, at p 229. 
often than not, when faced with measures that they either did not understand or simply disliked, Khmers did what Khmers have done for centuries; they fled the net of authority. In South East Asia, a region where human populations were a more vital resource than territory, group flight was a traditional means of pressuring regional governors to ease demands upon local populations. ${ }^{112}$ For the plague, urban dwellers fled not only from the city of Phnom Penh, but also from smaller afflicted towns. The seaside town of Kampot saw periodic flights with each epidemic. Municipal doctors registered a handful of plague deaths among those smuggled out of the provincial centre of Prey Veng when already sick. ${ }^{113}$ Dr Haelwyn, the Municipal Doctor of Battambang complained,

As soon as an epidemic breaks out, the inhabitants avoid coming to alert the authorities because, more than the disease, they fear our methods of prevention and disinfection, which they consider troublesome.... The population carefully hides its sick, furtively buries its dead. ${ }^{114}$

In 1910, the Health Director commented that the Phnom Penh Municipal Doctor spent more of his time trying to track down suspicious cases than in treating the sick. ${ }^{15}$ In an extreme example, Dr Bernard Menaut spent months in 1916 trying to locate three monks at Wat Sarawan in Phnom Penh who refused to be vaccinated. ${ }^{116}$ People fled not only from epidemic measures. For example, in 1928, two young women

112 See Adas, M. (1998), 'From footdragging to flight: the evasive history of peasant avoidance protest in South and Southeast Asia', Essay 2, State, Market, and Peasant in Colonial South and Southeast Asia, Ashgate, Brookfield, VT; Reid, A. (1988), Southeast Asia in the Age of Commerce: 1450-1680, Volume One: The Lands Below the Winds, Chapter 2, Yale University Press, New Haven, CT; Tarling, N., ed (1992), The Cambridge History of Southeast Asia: Volume 2 part one: From c.1800 to the 1930s, Vol 2, Cambridge University Press, Cambridge, p 110. See also the collected essays in Kerkvliet, B. J. T., and Scott, J., eds (1986), Everyday Forms of Peasant Resistance in Southeast Asia, Frank Cass, Totowa, NJ.

113 NAC RSC 9631.

114 NAC RSC 1315, 1346.

115 NAC RSC 1315.

116 The monks, visiting from another wat, had stood by watching while the public health officials were burning the cell of a dead monk. When they refused vaccination, the attendant recorded their names along with a few other local monks who had refused vaccination. The monks of Wat Sarawan were soon vaccinated due to pressure from the achaar, but these three could not be found. With the hope that their higher visibility as monks would aid in their discovery, the public health officials enlisted the aid of the Khmer Council of Ministers in locating these individuals. Information led Menaut to the hinterlands of Mandap, where several weeks of wandering and questioning led him nowhere. NAC RSC 1315. 
disappeared while being transported to Saigon to complete rabies treatment after being bitten by rabid dogs. The Health Director wrote in exasperation, 'Perhaps, would it be possible to seek these patients with the use of the police, and to get their families to understand the danger that follows from their lack of foresight?' ${ }^{117}$

\section{Meanings and motives}

One of the key ambitions in agrarian studies is to explore the meanings and motives behind peasant resistance and rebellion. James Scott has argued that peasant politics is imbued with an essentially moral economy. The moral economy of peasants makes them less inclined to individual high-risk behaviour and more inclined to communal risk sharing. They have a greater desire to minimize the probability of disaster than to maximize possible return - in other words, they care much more about what is left rather than what is taken. Thus peasants are more likely to rebel when safety nets are threatened. ${ }^{118}$ The social unrest discussed above certainly cannot be called full-scale rebellion. However, the widespread disorder in Phnom Penh during the first two years of plague can illuminate at least some motivations for peasant protest, identifying acts sufficiently unbearable to drive the unprotected to resist. In fact, one could argue that the less politically grandiose nature of the events examined above provides a more quotidian perspective on peasant resistance. Such acts are a historically neglected middle ground between everyday resistance and revolution.

The events following the 'ridiculous pig incineration' would seem to support the idea of moral economy. Khmer families raised (and still raise) pigs as an important security for times of famine or economic hardship. As such, their killing would eliminate an important economic safety net for the poorest people. Before the pig killings, the AM

NAC RSC 1156.

118 Scott, J. C. (1976), The Moral Economy of the Peasant: Rebellion and Subsistence in Southeast Asia, Yale University Press, New Haven, CT. Scott has his critics, most notable among them being Samuel Popkin, who wrote against Scott and other moral economy proponents such as Eric Wolf and Clifford Geertz. He argued that peasants were essentially 'rational'. They operated within a political economy as much or more than in a moral economy worldview. In Popkin's formulation, peasants rebelled because they were both anticolonial and antifeudal, recognizing their exploitation from both 'premodern' and colonial structures. Popkin, S. L. (1979), The Rational Peasant: The Political Economy of Rural Society in Vietnam, University of California Press, Berkeley, CA. 
had removed physical samples of the deceased and dying without family consent, taken the sick forcibly to the lazaret, and injected villagers with serum. These were acts upon human bodies, living human beings. Yet they did not cause rioting. The demonstrations began immediately with the pig killings. However, a direct connection between the slaughter and the rioting cannot be too strongly drawn. First, the pig killings coincided with the first deaths in the Khmer quarter. The Sino-Khmer population had had to contend with public health measures before the Khmer population, which may have been somewhat insulated from the measures in the Chinese quarter. Thus, the poorer Khmer population would have been presented with several frightening and bewildering behaviours at once in their initial interaction with French public health measures. Indeed, the only obvious link between the killing of pigs, painful injections and the frightening new disease in their midst was the French authorities. The larger riots of the second year support this. The perceived lack of respect for Khmer dead, particularly the lack of respect for the woman's corpse, was the main objection during the second-year protests and in the investigation that followed. However, as crowd historian Rudé pointed out, a crowd is heterogeneous in its aims and motivations, even if it crystallizes around a central issue, and the nature of a crowd is evolving, often changing goals during the process of protest. ${ }^{119}$ While the pig killings certainly drove many townsfolk to doubt both the good intentions and perhaps the sanity of the local health services, the home invasions and offence to modesty committed by the military doctor had created preconditions for resentment and distrust.

The rumours cited by the colonial government also point to another significant difference in indigenous understandings of what was occurring. ${ }^{120}$ If they used their recent history as a basis of judgment, the Khmer population could interpret the intense French involvement only as negative. People were not fleeing the plague. People were fleeing the French measures against the plague. The danger of 'contagion' was not seen to be as threatening as the tangible dangers represented by French measures to counteract contagion. Further, the reality of the pain resulting from the Yersin injection, and the loss of security from

119 Rudé, supra note 91, Chapter 1.

120 For a provocative essay on the role of rumour in facilitating indigenous interpretations of foreign technologies, see White, L. (1993), 'Cars out of place: vampires, technology, and labor in East and Central Africa', Representations, Vol 43, pp 2750 . 
the killing of a pig was a greater impetus to flight than the abstract notion of contagion. Villagers were not fleeing vaccinations; they were fleeing the volatile European. The Moung-Roussey villagers did not want a 'modern' vaccinator; they wanted their variolator returned. In fact, the Kompong Cham petition against Fabry was one of the rare complaints against a doctor for not doing his job. As the section on evasion revealed, the general population seemed to want little more than to be left alone.

In all, the actions of the Khmer population, elite and peasant, crystallize around issues of respect and morality. For instance, Fabry's land-grabbing was almost a footnote in the Kampong Cham petition, whereas his more favourable treatment of a richer Vietnamese than a Khmer, and his wife's abusive treatment of staff were emphasized in detail. For the living, the perception of respect in personal interactions was far more important than physical force on the living body. Although people fled or refused vaccinations, almost no complaints were registered against the evacuation of the sick to the lazarets or the examinations of the living. The greatest complaints were against the physical treatment of the dead, rather than the treatment of the living. These incidents particularly reveal that the woman's body was a highly privileged domain. In contrast to much of the existing scholarship on peasant politics in South East Asia, which relies heavily on economic models, these vignettes emphasize the importance of perceived respect in personal reactions. Economics can often be secondary to other motivations for resistance. These middle-ground events reveal both pragmatic/rational and emotional responses to unreasonable demands from individuals and from the state.

Despite colonial efforts at public dissemination of information, epidemic measures ultimately led to conflicts. In large part, this was because of French misunderstanding of the fundamental reasoning behind local choices. Too often, officials lumped Khmer behaviour into obscuring categories of faint-heartedness, prudishness or contrariness. On the Khmer side, understanding was no clearer. Pathoma's refusal to be vaccinated, the notion of quota in the Cham petition, Khanarac's lackadaisical postponement of vaccination, the pig killings, the request for the imprisoned variolator, the flight of the girls undergoing rabies treatment - all these examples show that the Khmer population misunderstood and deeply distrusted French medicine. Naturally, they wanted nothing to do with it. 


\section{Dual polities}

The process of medical imposition occurred concurrently with state imposition in Cambodia. In other words, the AM was established at approximately the same time as the French colonial government had the will and the means to infiltrate peasant society. The formation of the colonial state was a top-down process of establishing authority. We have no detailed studies of the relationship between the Khmer state and society in the period immediately preceding French colonialism. We do have a general model, however, in Clifford Geertz's formulation of the 'theatre state'. Geertz claims that the pre-colonial South East Asian state was actuated from the bottom up. He writes,

The right to command was not delegated from king to lord, lord to lordling, and lordling to subject; rather, it was surrendered from subject to lordling, lordling to lord, and lord to king. Power was not allocated from the top, it was cumulated from the bottom. This is not to say that the system was democratic, which it certainly was not; nor that it was libertarian, which it was even less. It is to say that it was - radically, pervasively, inveterately - confederate. ${ }^{121}$

Within this system, '[t]he driving aim of higher politics was to construct a state by constructing a king. The more consummate the king, the more exemplary the center. The more exemplary the center, the more actual the realm.' 122 The right of the king to govern, to convince those beneath to surrender power to him, was determined by his ability to display this exemplary centre on earth through pomp. In contrast, in the framework of European government, 'the office of the dignified parts is to serve the efficient, that they are artifices, more or less cunning, more or less illusional, designed to facilitate the prosier aims of role. Political symbology...is but the instrument of purposes concealed beneath it or towering above it. ${ }^{\prime 23}$ How well Geertz's model would satisfy a detailed study of pre-colonial Cambodia is uncertain. Thus, it is only presented here as one hypothetical model of the relationship between the Khmer government and its people. However, we can reasonably speculate that the relationship between the ruler and ruled in Cambodia was fundamentally changed with the imposition of colonialism. Moreover, there was a disjuncture between the pre-colonial and colonial form of government and the way non-state

121 Geertz, C. (1980), Negara: The Theatre State in Nineteenth-Century Bali, Princeton University Press, Princeton, NJ, pp 62-63.

122 Ibid, p 124.

123 Geertz, supra note 121, at p 122. 
actors interpreted acts of this foreign state. Ultimately, "[t]he symbols of collective action cannot be simply read like a "text", independent of the conditions in which they struggle. Nor are they simple projections of indigenous culture into political strategies.' ${ }^{24}$ They are chosen, 'frames' to relate text to context, to present claims effectively both within the protesting group and to the authority.

At the minimum, two conceptions of the state coexisted for much of the colonial period. The way in which the majority of the indigenous actors conceived of the state did not change the moment formal control of government changed. While the two ideologies of state necessarily collided at some point, most histories take it as a given that the 'reality' of colonial domination immediately informed peasant response to colonial/state action. This can be inaccurate. One subaltern scholar of India, writing against the tendency to describe peasant behaviour as non-political, argues, 'The semiotics of domination and subordination were what the subaltern sought to destroy every time they rose up in rebellion' ${ }^{125}$ Such acts, according to some subalternists, are inherently political, anticolonial and antifeudal. ${ }^{126}$ However, these stories of medicine in Cambodia reveal that indigenous society did not immediately react to colonial hegemony as modern political actors against a Western concept of the state. In other words, the statement needs qualification in the Khmer context. The acts of resistance were political, but were originally framed within a pre-existing concept of polity. If within the theatre state there are in a sense no 'non-state' actors (since the people actuate the state), then these collective acts of 'resistance against the state' could more accurately be viewed as expressions of 'negotiation within the state'. While the populace may have viewed it as such, the colonial state (and many post-colonial scholars) interpreted it within a Western political trajectory as a much more significant rupture. A political shift did occur in the colonial period, but it did not occur immediately.

Confrontational acts must thus be read in the context of both Khmer political systems and the French colonial government. The Khmer peasantry were acting politically, but they were in fact often attempting to negotiate with and correct another, different concept of the state. The French colonial government, the effective state, responded in

124 Tarrow, supra note 20, at p 109.

125 Chakrabarty, D. (2000), 'Subaltern studies and postcolonial historiography', Nepantla: Views from the South, Vol 1, No 1, pp 1-32, pp 17-18.

126 This is reminiscent of Popkin's formulation of the rational peasant; see note 118 . 
unexpected ways, and this created further misunderstanding. Moreover, the Khmer elite, Chinese minorities and other groups had still different understandings of their relationship to the colonial government and expressed their resistance in a variety of ways. But their relationships with each other and with the French colonial government were also being renegotiated throughout the colonial period. To understand the motivations for their actions, we must keep in mind the gradual, if transformative, aspects of the imposition of both Western medicine and the Western bureaucratic state.

\section{Archival sources}

Archives of the Institut Pasteur (AIP), Paris

Archives of the Société Asiatique, Fonds Aymonier, Paris

National Archives of Cambodia, Collection of the Résidence Supérieur du Cambodge (NAC RSC), Phnom Penh

\section{References}

Adas, M. (1981), 'From avoidance to confrontation: peasant protest in precolonial and colonial Southeast Asia', Comparative Studies of Society and History, Vol 23, No 2, pp 217-247.

Adas, M. (1992), 'Comment on "From avoidance to confrontation"”, in Dirks, N. B., ed, Colonialism and Culture, University of Michigan Press, Ann Arbor, MI, pp 127134.

Adas, M. (1998), State, Market, and Peasant in Colonial South and Southeast Asia, Ashgate, Brookfield, VT.

Aymonier, E. (1984/83), Notes sur les coutumes et croyances superstitieuses des cambodgiens, CEDORECK, Paris.

Barnes, D. S. (1995), The Making of a Social Disease: Tuberculosis in Nineteenth-Century France, University of California Press, Berkeley, CA.

Benedict, R. (1968), 'The relativity of normality', in Fried, M. H., ed, Readings in Anthropology, Thomas Crowell Co, New York, pp 791-808.

Chakrabarty, D. (2000), 'Subaltern studies and postcolonial historiography', Nepantla: Views from the South, Vol 1, No 1, pp 1-32.

Chandler, D. (1974), 'Royally sponsored human sacrifice in nineteenth century Cambodia: the cult of the Nak Ta Me Sa (Mahisasuramardini) at Ba Phnom', Journal of the Siam Society, Vol 62, No 2, pp 207-222.

Chandler, D. (1982), 'The assassination of Resident Bardez (1925): a premonition of revolt in colonial Cambodia', Journal of the Siam Society, Vol 70, No 1, pp 35-49.

Chandler, D. (1992), Brother Number One: A Political Biography of Pol Pot, Westview Press, Boulder, CO.

Choulean, A. (1986), Les êtres surnaturels dans la religion populaire khmère, CEDORECK, Paris.

Ebihara, M. (1971), 'Svay, a rice growing village: 1958-1960', PhD thesis, Anthropology Department, Columbia University, New York.

Edwards, P. (1999), 'Cambodge: the cultivation of a nation', PhD thesis, History Department, Monash University, Melbourne. 
Forest, A. (1992), Le culte des genies protecteurs au Cambodge: Analysis et traduction d'un corpus de textes sur les neak ta, Harmattan, Paris.

Furnivall, J. S. (1956), Colonial Policy and Practice: A Comparative Study of Burma and Netherlands India, New York University Press, New York.

Geertz, C. (1980), Negara: The Theatre State in Nineteenth-Century Bali, Princeton University Press, Princeton.

Guénel, A. (1995), 'Lutte contre la variole en Indochine: variolisation contre vaccination', History and Philosophy of the Life Sciences, Vol 17, pp 55-70.

Guénel, A. (1996), 'La lutte antivariolique en Extrême-Orient: ruptures et continuité', in Moulin, A. M., ed, L'Aventure de la Vaccination, Fayard, Paris, pp 82-94.

Hardy, A. (1993), The Epidemic Streets: Infectious Disease and the Rise of Preventive Medicine, 1856-1900, Clarendon Press, Oxford.

Kerkvliet, B. J. T., and Scott, J., eds (1986), Everyday Forms of Peasant Resistance in Southeast Asia, Frank Cass, Totowa, NJ.

Mak, P. (1995), Histoire du Cambodge: De la fin du XVIe siêcle au debut du XVIIIe, Presses de l'Ecole française d'Extrême-Orient, Paris.

Martel, G. (1975), Lovea, village des environs d'Angkor: Aspects demographiques, economiques et sociologiques du monde rural cambodgien dans la province de SiemReap, Ecole Française d'Extrême Orient, Paris.

Müller, G. (2002), 'Visions of grandeur, tales of failure', PhD thesis, History Department, University of Zurich, Switzerland.

Osborne, M. (1978), 'Peasant politics in Cambodia: the 1916 affair', Modern Asian Studies, Vol 12, No 2, pp 217-243.

Ovesen, J. (1996), When Every Household is an Island: Social Organization and Power Structures in Rural Cambodia, Department of Cultural Anthropology, Uppsala University, Sida, Uppsala, Sweden.

Pannetier, A., and Verneau, R. (1921), 'Contribution a l'étude des Cambodgiens', L'Anthropologie, Vol 31, pp 279-317.

Pannetier, D. A. (1983), Au coeur du pays khmer: Notes cambodgiennes, CEDORECK, Paris.

Popkin, S. L. (1979), The Rational Peasant: The Political Economy of Rural Society in Vietnam, University of California Press, Berkeley, CA.

Reid, A. (1988), Southeast Asia in the Age of Commerce: 1450-1680, Volume One: The Lands Below the Winds, Yale University Press, New Haven, CT.

Reid, A. (2000), Charting the Shape of Early Modern Southeast Asia, Institute of Southeast Asian Studies, Singapore.

Robequain, C. (1944), The Economic Development of French Indo-China, Oxford University Press, New York.

Rudé, G. (1964), The Crowd in History, 1730-1848, John Wiley \& Sons, New York.

Scott, J. C. (1976), The Moral Economy of the Peasant: Rebellion and Subsistence in Southeast Asia, Yale University Press, New Haven, CT.

Scott, J. C. (1985), Weapons of the Weak: Everyday Forms of Peasant Resistance, Yale University Press, New Haven, CT.

Scott, J. C. (1990), Domination and the Arts of Resistance: Hidden Transcripts, Yale University Press, New Haven, CT.

Shiraishi, T. (1990), An Age in Motion: Popular Radicalism in Java, 1912-1926, Cornell University Press, Ithaca, NY.

Spores, J. C. (1988), Running Amok: An Historical Inquiry, Ohio University Center for International Studies, Athens, $\mathrm{OH}$.

Tarling, N., ed (1992), The Cambridge History of Southeast Asia: Volume 2 part one: From c.1800 to the 1930s, Vol 2, Cambridge University Press, Cambridge.

Tarrow, S. G. (1998), Power in Movement: Social Movements and Contentious Politics, Cambridge University Press, Cambridge and New York. 
Tauch, C. (1994), Battambang During the Time of the Lord Governor, CEDORECK, Phnom Penh.

Thompson, V. M. (1937), French Indo-China, Macmillan, New York.

Tilly, C. (1986), The Contentious French, Belknap Press, Cambridge.

Tilly, C. (1995), Popular Contention in Great Britain, 1758-1834, Harvard University Press, Cambridge, MA.

Vickery, M. (1984), Cambodia, 1975-1982, South End Press, Boston, MA.

Weber, M. (1947), The Theory of Social and Economic Organization, The Free Press, New York.

White, L. (1993), 'Cars out of place: vampires, technology, and labor in East and Central Africa', Representations, Vol 43, pp 27-50.

Wilmott, W. E. (1967), The Chinese in Cambodia, University of British Columbia Publications, Vancouver. 